\title{
Konya Sultan Selim (Süleymaniye) Camii Biçim Özellikleri ve Müellif Mimar Meselesine Bir Katkı
}

\author{
Formal Features of Konya Sultan Selim (Suleymaniye) Mosque and a Contribution to \\ The Subject of Authorship
}

\author{
Ali Naci Özyalvaç ${ }^{\star}$ (
}

Öz

Konya'da Mevlânâ Dergâhı'nın batısında bulunan Sultan Selim Camii yapım tarihi, banisi ve mimarının kimliği konusunda muhtelif görüşler bulunan önemli bir klasik dönem eseridir. Tarihi kent merkezinde içinde bulunduğu yapılar topluluğu, XX. yüzyılda yıkımlar ile bütünlüğünü yitirmişse de caminin yörenin sahip olduğu en nitelikli Osmanlı mimarlığı örneği olması vasfı devam etmiştir. Sultan Süleyman'ın padişahlığı ve Mimar Sinan'ın mimarbaşılığı dönemine tarihlenen yapının Sinan'ın eserlerini veren listelerde yer almayışı yanında, kitle kompozisyonu açısından daha erken dönem örnekleri çağrıştırması sebebiyle müelliflik konusu şimdiye dek açıkığa kavuşmamıştır. Bu çalışmada amaç, yapının mekân boyutları ve kemer biçimlenişleri gibi biçimsel özelliklerinin diğer yapılar ile kıyaslanması yoluyla tasarım yaklaşımlarını inceleyerek İstanbul'da Sinan dönemi camilerindeki benzer tutumların araştırılmasıdır. Yöntem olarak güncel rölöveler ve yerinde ölçümler ile daha önceden İstanbul'da Mimar Sinan dönemi camileri üzerine yaptığımız katalog çalışmasına müracaat edilmektedir. Sonuç olarak ilk kez Sultan Selim Camii'nde iç mekân, son cemaat yeri ve cephelerde kullanılan kemer tipleri kuruluş ilkeleri bakımından sınıflandırımış ve bu tiplerin kullanıldığı diğer yapılar ile değerlendirilmiştir. Netice olarak yapının Sultan Selim'in tahta çıktığı ve Sinan'ın mimarbaşı olarak görev yapmakta olduğu dönemde başkentte inşa edilmiş önemli yapılar ile benzerlikleri ortaya konmuş ve yapım tarihine ilişkin 1560 ve sonrasını işaret eden iddiaları destekleyecek sonuçlara ulaşılmıştır. Ayrıca mekân boyutları ve duvar teşkilatı gibi açılardan yapılar kıyaslanmış, plan ve kesit düzlemlerinde oran kullanımı hakkında burada ulaşılan bilgiler ile konunun genişletilerek devam ettirilmesinin gerekliliği ortaya çıkmıştır. Yapının tümel ifadesi hakkında yapılan yorumlar somut veriler ile teyit edilmekle birlikte kullanılan kemer tipleri bakımından çağdaşı olduğu yapılar arasında olgun ve seçkin bir örnek olarak beliren eser, bu yönde yeni çalışmalar ile ele alınmayı beklemektedir.

\section{Anahtar Kelimeler}

Konya Sultan Selim Camii, Mimar Sinan, Sivri Kemer, Müellif

\begin{abstract}
Sultan Selim Mosque is an important classical period work located to the west of Mevlânâ Dervish Lodge in Konya, and there are various opinions about the date of construction, the patron and identity of the architect. Due to the absence of inscriptions, foundation records, construction exploration books or in-state correspondence, it is important to turn directly to the mosque, which is one of the sultan mosques that Mimar Sinan was responsible for due to his position. As a method, with current surveys and on-site measurements, the lists that have previously been made in the catalog study on Mimar Sinan period mosques in Istanbul were benefited from. As a result, for the first time in the Sultan Selim Mosque,
\end{abstract}

* Sorumlu Yazar: Ali Naci Özyalvaç (Dr. Öğr. Üyesi), Konya Necmettin Erbakan Üniversitesi, Mühendislik ve Mimarlık Fakültesi, Mimarlık Bölümü, Konya, Türkiye. E-posta: aozyalvac@erbakan.edu.tr ORCID: 0000-0001-5596-0146

Atıf: Ozyalvac, Ali Naci. "Konya Sultan Selim (Süleymaniye) Camii Biçim Özellikleri ve Müellif Mimar Meselesine Bir Katkı." Art-Sanat, 14(2020): 323-347. https://doi.org/10.26650/artsanat.2020.14.0013 
the interior space, the narthex and the arch types used in the facades were classified in terms of establishment principles and it was possible to evaluate them with other structures in which they were used. As a result, the building's similarities with the important buildings built in the capital were revealed by this research during the period when Mimar Sinan was acting as the architect, and conclusions were reached to support the claims that point to 1560 and beyond as the date of construction. In addition to space measurements, wall designs and arch configurations, which are among the parameters used in the comparison of the mosques built in the Mimar Sinan period in Istanbul, the issue of the use of ratio in plan and section planes has emerged as a new title, and in this context the research needs to be continued. Although the comments about the overall expression of the building were confirmed with concrete data, the work, which appears as a mature and distinguished example among the buildings it is contemporary in, is waiting to be handled with new studies in this direction.

\section{Keywords}

Konya Sultan Selim Mosque, Mimar Sinan, Pointed Arch, Authorship

\section{Extended Summary}

Although the complex of buildings in the historical city center lost its integrity with the destructions in the $20^{\text {th }}$ century, the mosque continues to be the most qualified example of Ottoman architecture of the city. The issue of commissioning has not been clarified since its building, which has been dated to the sultanate of Sultan Süleyman and the architect of Mimar Sinan, and was not included in the lists that recorded the works of Sinan and evoked earlier examples of Ottoman architecture in terms of mass composition. There are various opinions about the construction date of the mosque, patronage and the architect. The documents related to the construction of the mosque in the documents belonging to the period of Suleyman the Magnificent were interpreted as the building was built by him. Some other researchers claimed that the building was built by Selim II, son of Sultan Süleyman, the governor of Konya. In addition to Mimar Sinan, the names of Architect Acem Ali (Alâeddin Ali Bey) and Architect Cemâleddin from Aleppo were proposed as the designers of the building, for which we do not have any information about its architect.

The aim of this study is to investigate similar attitudes in the Sinan period mosques in Istanbul by examining the design approaches by comparing the formal features of the building such as space dimensions and arch formation with other structures. If the arch types encountered in the building are considered together, it can also be seen that previous architectural experience gained from the construction of important works that were completed in Istanbul in the period of Mimar Sinan was used in this structure, prior to the date when the Sultan Selim Mosque was allegedly built. Interesting findings have been reached in terms of ratio research in horizontal and vertical projection planes, and the introduction of this design approach and comparison of this approach with other buildings will be considered as a separate publication.

The pointed arch (1) between two pillars bearing the central dome of the building in the direction of the qibla, the arches (2) connecting the feet to the wall buttress at the north of the harim, three pointed arches (3) that continue from the north wall to the 
mihrab wall on the east and west of the middle nave, the arches (4) that connect these feet and columns to the walls behind them, the arch (5) below the upper floor of the northern wall, the pointed arches (6) in the narthex porches on the north facade of the mosque and discharging arches (7) over the window and door openings were examined in terms of dimensions and centers of the arcs that set the arches up. Examples of two-centered pointed arches, which were built using points found by dividing the opening, are also found in the 19 mosques built in the Mimar Sinan period in Istanbul, which we have classified in our previous studies.

The arch (1) that connects the feet carrying the dome is a two-center pointed arch close to the circle with an opening of $12.85 \mathrm{~m}$ and a height of $6.50 \mathrm{~m}$ and similarly, on the other direction (2) has an opening of $13.70 \mathrm{~m}$ and both of them have a 1.52 $\mathrm{m}$ width in plan. These arches are the elements of rising cubic parts that dominate the structure's outer appearance. Zal Mahmut Pasha Mosque (1577) is similar to this structure in that the arches carrying the dome have a $12.42 \mathrm{~m}$ span and $6.32 \mathrm{~m}$ height. Fatih Bali Pasha (1546), Kılıç Ali Pasha (1581) and Üsküdar Mihrimah Sultan Mosques (1547) are the structures where the circular arch is used in a similar size.

The arches (3) between pillars at the springing line of $5.60 \mathrm{~m}$ above ground with a $6.00 \mathrm{~m}$ opening are all typical pencî pointed arches which are formed by dividing the span by 5 . The arches (4) that connect these feet and columns to the walls behind them are all these types of two centered pointed arches with approximately 5.30 to $6.00 \mathrm{~m}$ span size. The same type is frequently used in the discharging arches (7) over the window and door openings. There are similar pointed arches connecting the feet in the walls at the same elevation as the windows and doors under the small domes on the east-west facades of the harim. It is seen that this arch type is the most preferred type among the 19 Mimar Sinan period Istanbul mosques with 40 percent indoors. Fatih Nişancı Mehmet Pasha, which has an eight-supported plan scheme, and Fındıklı Molla Çelebi and Topkapı Kara Ahmet Pasha Mosques, which have a 6-supported scheme, are smaller applications where the arches carrying the main dome are this (1:5) type. In Şehzadebaşı, Süleymaniye, Üsküdar Atik Valide, Azapkapı Sokullu Mehmet Paşa and Üsküdar Mihrimah Sultan Mosque, such (1:5) arches dominate the interior appearance of the building. Similar examples of span size of these arches are $5.67 \mathrm{~m}$ in the Fındıklı Molla Çelebi Mosque, $5.70 \mathrm{~m}$ in the Topkapı Kara Ahmet Paşa Mosque and $5.70 \mathrm{~m}$ in the Şehzadebaşı Mosque.

The arch (5) with $2.65 \mathrm{~m}$ width in plan on the north wall on the entrance door is a round arch with $13.40 \mathrm{~m}$ span which has the springing line at $2.25 \mathrm{~m}$ above the floor. The narthex portico is wider and higher in the middle, three identical arches on each side, with seven pointed arches that sit on the walls on both sides and 6 columns in the middle. All of the arches (6) seen on the front and connecting the columns to the 
north wall are two-centered pointed arches consisting of springs drawn from the points found by dividing the opening by 7 . The pointed arches with an opening of $5.17 \mathrm{~m}$ in the first row of five-unit porticoes of the Üsküdar Mihrimah Sultan Mosque narthex are of the same type as the portico arches seen here. Süleymaniye Mosque courtyard porches are an example where both (1:5) and (1:7) proportioned pointed arches are used together. The ones used in the five-unit narthex porticoes of Eyüp Zal Mahmut Pasha Mosque are pointed arches with a $4.14 \mathrm{~m}$ span and (1:7) ratio, which is very similar to the arches we find here. We encounter the same type (1:7) at Üsküdar Atik Valide Mosque narthex on the east and west facades of the first-row porticoes with a $4.45 \mathrm{~m}$ span. Considering the data obtained, it is understood that Konya Sultan Selim Mosque can be evaluated with the works of Mimar Sinan in the first half of the $16^{\text {th }}$ century. In addition, it was seen that further research was needed to compare the works of pre-Sinan architects with their works to understand the reason of the visual similarity of the building with the pre-classical mosques. 


\section{Giriș}

Konya Sultan Selim (Süleymaniye) Camii şehrin merkezini işaret eden Mevlânâ Celâleddîn Rumî'nin kabri ve Mevlevî Dergâhı'nın yanı başında klasik dönem Osmanlı mimarisinin olgun bir örneği olarak yer almaktadır. Bu benzersiz konumuna karş1lık yapının inşa tarihi, banisi ve mimarının kim olduğu konusu tam olarak açıklığa kavuşmuş değildir. Kitabeler, vakfiyeler, inşaat keşif kayıtları veya yapımına ilişkin devlet içi yazışmaların bulunmayışı yahut bilinmeyişi sebebiyle selatin camilerinden olan bu kıymetli eserin kendisine müracaat etmek yolu önem kazanmaktadır. Bu çalışmada yapının mekân ölçüleri, duvar kesiti ve açıklık boyutları, kemer büyüklükleri ve kuruluş ilkeleri, yatay ve düşey plan düzlemlerinde oran araştırmaları ile yapının Mimar Sinan döneminde ve Sinan'ın selefi mimarların yapım tarzı ile karşılaştııılması, bu yolla müellif mimar konusundaki iddiaların incelenmesi amaçlanmaktadır. Günümüzde yapıların belgelenmiş olmaları ve ölçme imkânlarının kolaylaşmış olması çalışmayı mümkün kılmaktadır. Ayrıca daha önceki çalışmalarımızda İstanbul'da Mimar Sinan camilerinin kemer kuruluşları bakımından tasnif edilmiş olması, kıyas yapmaya olanak vermektedir. Sultan Selim (Selimiye) Camii'nin Sinan'ın İstanbul camileri ile kiyaslanması çalışmanın ilk bölümünü, yatay ve düşey düzlemlerde oran araştırması bakımından ilginç bulgulara ulaştığımız tasarım yaklaşımının ortaya konması ve bu yaklaşımın karşılaştırılması ikinci bölümünü oluşturmaktadır. İki farklı yaklaşım tarzı çalışmayı iki ayrı başlık hâlinde ele almayı gerekli kıldığından bölümler bağımsız yayınlar olarak ele alınmıştır. Yine de yapıların biçim özellikleri bakımından yapılacak bir kıyaslama için planimetrileri, cephe görünüşleri, taşıyıcı duvar teşkilatı, oran araştırması gibi alt başlıkların ayrıca detaylandırılması ihtiyacı yanında yapıların sayıca çokluğu, ölçüm, belgeleme ve yapılmış rölövelere ulaşmanın zaman alan süreçler olması sebebiyle ulaşılan sonuçların her zaman tashih edilmeye muhtaç olduğu teslim edilmelidir.

Konya Sultan Selim (Süleymaniye) Camii'nin yapım tarihi, banisi ve mimarının kimliği konusunda muhtelif görüşler bulunmaktadır. Kanuni Sultan Süleyman devrine ait belgelerde ${ }^{1}$ caminin yapımına ilişkin bilgiler bulunması yapının bu padişah tarafından yapıldığ şeklinde yorumlanmıştır. ${ }^{2}$ Diğer bir kısım araştırmacı bani olarak Konya sancak beyliği yapan Sultan Süleyman'ın oğlu Şehzade II. Selim'i göstermektedir. ${ }^{3}$ Semavi Eyice, yapıyı Mimar Sinan ve takipçileri dönemi içinde ele almış ve Yavuz Sultan Selim adına XVI. yüzyılın ilk yarısında yapılan eserin bir kubbe ve yarım kubbe düzeniyle ilk Fatih Camii mimarisinin adeta aynen tekrarladığını yazmıştır. ${ }^{4}$ Mimarına ilişkin bilgi sahibi olmadığımız yapı ile ilgili Mimar Sinan, Sinan öncesi Hassa Ocağı'nın başında bulunan Mimar Acem Ali'si olarak da bilinen Alâeddin Ali

1 Ankara Vakıflar Genel Müdürlüğü Arşivi, 475/7

2 Yusuf Küçükdağ, "Sultan Selim Camii ve Külliyesi,” TDV İslam Ansiklopedisi, c. 37 (İstanbul: Türkiye Diyanet Vakfi Yayınları, 2009), 516.

3 İbrahim Hakkı Konyalı, Âbideleri ve Kitâbeleri ile Konya Tarihi (Konya: Yeni Kitap Basımevi, 1964), 194.

4 Semavi Eyice, “Cami,” TDV İslam Ansiklopedisi, c.7 (İstanbul: Türkiye Diyanet Vakfı Yayınları, 1993), 80. 
Bey ${ }^{5}$ veya Halepli Mimar Cemâleddin isimleri ile karşılaşmaktayız. Ayrıca yapı plan özellikleri bakımından Hammer tarafından Ayasofya Camii ile kıyaslanmış ${ }^{6}$, Şahabettin Uzluk ${ }^{7}$ ve Metin Sözen ${ }^{8}$ eski Fatih Camii örnek alınarak yapıldığını iddia etmiştir. Aşağıda yapının başta mekân boyutları, beden duvarı ölçüleri ve sivri kemer biçimlenişleri olmak üzere bilinen diğer Sinan yapıları ile karşılaştırılması yapılarak öncelikle Sinan devri, özellikle de başkent İstanbul'da inşa edilmiş büyük ölçekli cami yapıları ile biçimsel benzerlikleri konusu irdelenecektir.
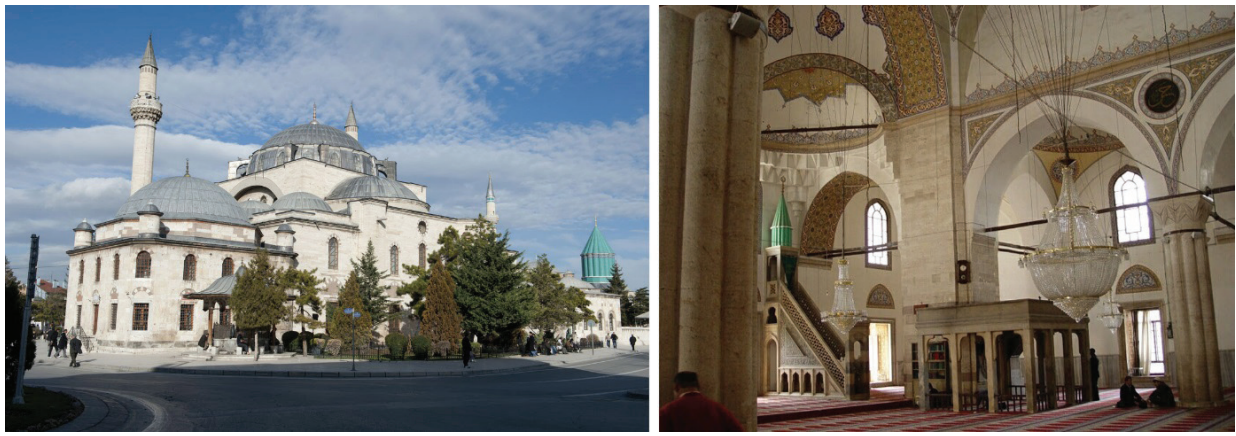

G. 1. Solda (a) Konya Sultan Selim Camii Dış Görünüşü

(Dick Osseman, 2010, https://pbase.com/dosseman/image/131990598)

Sağda (b) İç Mekân Batı Cephesi Görünüşü

(Dick Osseman, 2003 https://pbase.com/dosseman/image/28778983)

\section{Yapının Kısa Tarihçesi}

Konya'nın merkez Karatay ilçesinde Celâleddîn-i Rumî'nin türbesi etrafında gelişmiş Mevlânâ Dergâhı'nın batısında bulunan cami daha sonra yapı grubuna eklenen Sultan Selim imareti sebebiyle bugün Sultan Selim Camii veya Selimiye Camii olarak anılsa da kaynaklarda Cami-i Cedîd veya Cami-i Şerif-i Sultan Süleyman olarak geçmektedir. ${ }^{9}$ Osmanlı klasik mimarlığının Konya'daki en önemli örneği olan eser XX. yüzyılın ilk yarısına kadar Yusuf Ağa Kütüphanesi ile bugün artık ayakta olmayan imaret, iki medrese ve muvakkithaneden oluşan yapılar topluluğunun merkezinde yer almaktadır. Kuruluşundan itibaren sürekli olarak Osmanlı sultanları tarafından desteklenen Mevlânâ Dergâhı'nın çevresindeki derviş hücreleri ile III. Murad tarafından inşa ettirilen ${ }^{10}$ Sultan Selim Medresesi kaynaklarda Velediye, Celâliyye, Sultan Veled Medresesi olarak kayıtlı olup 1888 ve 1951 tarihlerinde yapılan yıkımlar ile ortadan

5 Zeki Sönmez, “Acem Ali,” TDV Íslam Ansiklopedisi, c.1 (İstanbul: Türkiye Diyanet Vakfi Yayınları, 1993 ), 322.

6 Joseph Von Hammer-Purgstall, Devlet-i Osmâniyye Târihi, trc. Mehmed Atâ (İstanbul: Mesai Matbaas1, 1329 [1913]), 3:95.

7 Şahabeddin Uzluk, “İstanbul'daki Eski Fatih Camii’nin Bir Benzeri Konya'da Selimiye Camii,” Vakıflar Dergisi 9 (1971), 177.

8 Metin Sözen, Türk Mimarisinin Gelişimi ve Mimar Sinan (İstanbul: Türkiye İş Bankası Kültür Yayınları, 1975), 185.

9 Yusuf Küçükdağ, "Sultan Selim Camii ve Külliyesi," 516.

10 Mehmet Önder, Mevlânâ Şehri Konya (Ankara: Konya Turizm Derneği Yayını, 1971), 395. 
kaldırılmıştır. ${ }^{11}$ Diğer medrese, bugün ayakta olan kütüphanenin de banisi, Sultan III. Selim'in annesi Mihrişah Valide Sultan'ın kethüdası Yusuf Ağa tarafından yaptırılmış mimari bakımdan kıymeti olmayan basit bir yapıdır ve aynı yıllarda ortadan kaldırılmıştır. Muvakkithane ise 1951 yılında yıkılmadan önce Yusuf Ağa Kütüphanesi’nin bitişiğinde bulunan kesme taştan yapılmış bir Abdülaziz dönemi eseridir. İmaretin yapım tarihi olarak kesin olmamakla birlikte Konya'da valilik yapan Şehzade II. Selim'in yeni yaptırdığı imaret için gelir olması amacıyla babası Sultan Süleyman tarafından birçok köy, mezra ve tarlanın gelirinin tahsis edilmesi emrini verdiği 1563 yılı kabul edilmektedir. 1965 yılında uzun süre bakımsız kaldıktan sonra yıkılarak yerine park yapılan eserin vakfiyesinde mimari programı hakkında detaylı bilgi bulunmaktadır. ${ }^{12}$ Sultan II. Selim'in aynı tarihlerde Konya'nın Karapınar ilçesinde yaptırdığı imaretin mimar Halepli Cemâleddin tarafından yapıldığının ortaya çıkması sonrasında yakın zamanlı bu yapının da mimarı olarak görevlendirilmiş olduğu iddiaları gündeme gelmiştir. ${ }^{13}$

İbrahim Hakkı Konyalı'ya göre caminin inşasına Sultan Süleyman'ın sağlığında başlanmış ve yapımı kendisinin vefatından sonra oğlu II. Selim tarafından tamamlanmıştır. Yapıldığı dönemde Yeni Cami olarak anılan eserin III. Murad zamanında Sultan Süleyman Camii olarak geçtiğini söyleyen Konyalı, dönemin yazılı kaynaklarından bu bilgiyi teyit eder. ${ }^{14}$ Tarih-i Peçevî yazarı İbrahim Peçevî, Tarih-i Solakzade yazarı Mehmed Hemdemî, Hasanbeyzade Ahmed Paşa ve Kühnül Ahbâr yazarı Âli Mustafa Efendi cami ile ilgili bilgi veren müelliflerden bazılarıdır. ${ }^{15}$ Evliya Çelebi meşhur eserinde "Câmi'-i Sultân Süleymân Hân iki minaresi ve birer tabakalı ve vâsi" haremli kıbâbları rasâs-1 hâs ile mestûr bir câmi'-i pür nûr-1 ma'mûrdur."16 demektedir. Tarih-i Atâ ${ }^{17}$ ve Süleymannâme $e^{18}$ aynı şekilde yapıyı Kanuni Sultan Süleyman'a mal eder. Hammer bu kaynaklara dayanarak aynı bilgiyi kabul etmiştir. ${ }^{19}$ Konyalı da birçok diğer yazar gibi Matrakçı Nasuh'un ünlü eseri Beyân-ı Menâzil-i Sefer-i Irâkeyn'de Konya'nın XVI. yüzyıl ilk çeyreğini gösteren resimlerinde Mevlânâ külliyesinin bulunduğu mevkide caminin olmadığını, türbe, tek minareli mescid, hatta şadırvan ve avlu duvarlarının seçilebildiği hâlde iki minareli Süleyman Camii’nin resmedilmeyişinden hareketle yapının bu tarihte mevcut olmadığını kabul etmek gerektiğini belirtmiştir. ${ }^{20}$

11 Caner Arabacı, Osmanlı Dönemi Konya Medreseleri (1900-1924) (Konya: KTO, 1998), 108-111, 333-337.

12 Ankara Vakıflar Genel Müdürlüğü Arşivi, 734/168.

13 Yusuf Küçükdağ, Karapınar Sultan Selim Külliyesi (Konya: Karapınar Belediyesi Yayını, 1997), 31-32.

14 Konyalı, Âbideleri ve Kitâbeleri ile Konya Tarihi, 194.

15 Peçevî İbrahim Efendi, Tarih-i Peçevî (İstanbul: Matbaa-1 Amire, 1864), 1:246; Solakzâde Mehmed Hemdemî, Solakzade Tarihi (Ankara: Kültür Bakanlığı Yayınları, 1989), 587.

16 Evliya Çelebi, Evliya Çelebi Seyahatnâmesi, haz. Seyit Ali Kahraman ve Yücel Dağlı (İstanbul: Yapı Kredi Yayınları, 2013), 3: 17.

17 Atâ Bey, Tarih-i Atâ (İstanbul: Basiret Matbaası, 1874), 1: 126.

18 Karaçelebizâde Abdülaziz Efendi, Süleymannâme (Kahire: Bulak Matbaası, 1832), 197.

19 Joseph Von Hammer-Purgstall, Devlet-i Osmâniyye Târihi, trc. Mehmed Atâ (İstanbul: Nefaset Matbaas1, 1332 [1916]), 6: 153.

20 Konyal, Âbideleri ve Kitâbeleri ile Konya Tarihi, 195. 

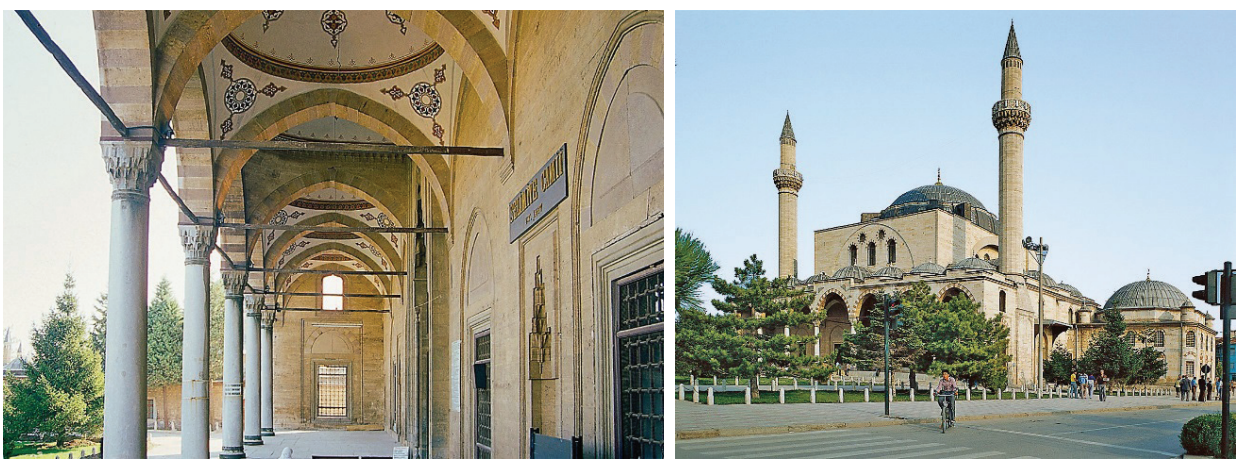

G. 2. Solda (a) Konya Sultan Selim Camii Son Cemaat Yeri, Sağda (b) Sultan Selim Camii ve

Yusuf Ağa Kütüphanesi Dış Görünüşü (Küçükdağ, “Sultan Selim Camii ve Külliyesi,” 516-517)

Aslanapa Osmanlı Devri Mimarisi'nde Konya Sultan Selim Camii'ni II. Selim'in ilk yıllarında yapılan camiler arasında sayar ve Selim'in şehzadeliği sırasında yapımına başlanılan eserin padişahlığının ilk yıllarında 1566 'da tamamlandığını belirtir. ${ }^{21}$ Yine Konya'daki en önemli Osmanlı mimarisi ürünü olarak gösterdiği yapının Eski Fatih Camii'nin abidevi ölçülerde yeniden ele alındığı klasik dönemin önemli bir ürünü olduğunu söyler. Yapının II. Selim tarafından babası adına yaptıııldığı için kendi adına kitabe koydurmadığını ifade eden Aslanapa yapının müellifi konusunda Mimar Sinan'ın o dönemde Hassa mimarlarının başı olduğu hâlde tezkirelerde yapı adının geçmediğini, bu dönemde yapılan bir selatin camiinin Sinan'ın ilgisinden kayıtsız olmasının mümkün olmadığını, yine de kişisel görüşü olarak dört duvar üzerinde oldukça ağır bir kitle hâlinde yükseltilen orta kubbenin Sinan'ın kıvrak üslubu ile uyumlu olmadığını kaydetmiştir.

Müelliflik sorunu hakkında fikir beyan eden az sayıda kişi arasında bulunan ve Anadolu Türk İslam Mimarisi'nde sanatçılar konusunda çalışmaları ile tanınmış Sönmez, kitabeleri bulunmamasına rağmen üslup özellikleri ve yapım tarihleri dikkate alınarak Konya Sultan Selim Camii'ni Saraybosna Gazi Hüsrev Bey Külliyesi, Trabzon Hatuniye, Manisa Sultan, Çorlu Süleymaniye, Tekirdağ Saray Ayas Paşa, Fatih Bâli Paşa, Sütlüce ve Silivri Pirî Mehmet Paşa camileri ile birlikte Acem Ali olarak bilinen Alâeddin Ali Bey isimli Hassa başmimarına bağlamaktadır. ${ }^{22}$ Mimar Sinan'ın selefi olan Acem Ali'nin önemli eseri İstanbul Yavuz Selim Camii, kendi üslubunu eksiksiz ortaya koyduğu bir örnek olarak gösterilmiştir. Bu yapı ile incelediğimiz yapının biçim özellikleri ve tasarımda oran kullanımı açısından irdelenmesi tek bir makale hacmini aşacağı için ayrıca ele alınması uygun görülmüştür.

Aptullah Kuran da aynı şekilde yapının Sinan'ın öz yapıları arasında sayılmasının mümkün olmadığını iddia etmektedir. ${ }^{23}$ Eski Fatih ve Gözleve Tatar Han camilerinin

21 Oktay Aslanapa, Osmanlı Devri Mimarisi (İstanbul: İnkılap Yayınları, 2004), 276.

22 Sönmez, "Acem Ali," 322.

23 Aptullah Kuran, Mimar Sinan (İstanbul: Hürriyet Vakfı Yayınları, 1986), 157. 
plan şemasını tekrarlayan Konya Selimiye Camii'nin II. Bayezid ve Yavuz Sultan Selim dönemlerini hatırlatan keskin köşeli kitle kuruluşu ve uçları kapalı son cemaat revakına bakıldığında Sinan'ın 1560'lı yıllarda eriştiği mimari üslup ile bağdaştırmanın son derece güç olduğunu ifade eden yazar Sultan Selim Camii'nin başka bir mimar tarafından yapılmış olması gerektiğini söyler. Bununla birlikte Konya Karapınar ilçesinde bulunan II. Selim Camii'nin tezkirelerde kayıtlı olduğundan hareketle Sinan'in önemli eserlerinden biri olduğunu, kitle kuruluşu, yatay ve düşey planlarda kusursuz oranları ile İstanbul'da tasarlanıp merkezden gönderilen yetenekli bir mimarın gözetiminde gerçekleştirildiği kanısındadır. Konya'yı Adana'ya bağlayan kervan yolu üzerindeki menzil külliyesinin kervansaray ve imaret bölümleri cami yapısından ayrı ele alınabilir. Ancak son yıllarda ortaya çıkartılan belgelerde Şehzade Selim'in Karapınar'da bir mescid, bir han ve bir hamam inşa ettirmek için kadıdan aldığı ilâmı Sultan Süleyman'a gönderdiği, Halepli Mimar Cemâleddin'in yapının inşasında görevlendirilmesini talep ettiği ve bu konuda istenen kişinin tayin edildiğini bildiren 1560 tarihli bir Hatt-1 Hümâyun sâdır olduğu, Halep kadısından mimarın acilen gönderilmesinin istendiği anlaşılmıştır. ${ }^{24}$ Daha sonra ortaya çıkan başka bir belgede ise Karapınar Sultan Selim Camii inşasının başlangıcından bitirilişine kadar Hassa mimarlarından Mimar Mehmed'in görevlendirildiği ortaya çıkmıştır. ${ }^{25}$ Mimar Mehmed'in yapının tasarım ve inşasındaki rolü, Halepli Mimar Cemâleddin'in Karapınar'a gelmiş olup olmadığı gibi konular daha uzun tartışmaları ve incelemeleri gerektirmektedir. Burada kısaca değindiğimiz bu olay da göstermektedir ki Sinan devri eserleri incelenirken bu eserlerin bir kişiden ziyade bir teşkilatın, Hassa Mimarlar Ocağı'nın ürünü olduğu gerçeği akıldan çıkarılmamalıdır.

Necipoğlu'na göre caminin inşasına 1559 yılında Konya surlarının dışında padişahın iki şehzadesi Bayezid ve Selim arasında ortaya çıkan taht mücadelesinden kısa süre sonra başlanmış olması mümkündür ve inşa edilmesi sürecinin bu bağlamda ele alınması gereklidir. ${ }^{26}$ Nitekim Mustafa Âli de bu yıllarda Sultan Süleyman tarafından şeyhin nurlu kabri yanında kubbeli bir mescid, daha sonra 1559-1560'ta türbesine bitişik kubbeli semâhâne ve dergâhın yanı başına iki minareli latif bir cami eklettiğini bildirir. Yine aynı yazar Selim'in kardeşi karşısında zafer kazanmasını babası Sultan Süleyman'ın ve Konya evliyalarının ruhaniyetine bağlar, isyancı kardeşi Bayezid'i evliya mezarlarının toplandığı Konya şehrinin temiz toprağını kirletmekle suçlar: "Asi şehzade ziyaretgâh ve nazargâh-1 Allah olan evliya mezarlarına saygısızlık ettiği için başta Mevlânâ Celâleddîn olmak üzere Şems-i Tebrîzî ve Şeyh Sadreddin Konevî gibi evliyalar onun gururuna müthiş bir sille vurdular, böylece şehzade takdir-i rabbanî

24 Küçükdağ, Karapınar Sultan Selim Külliyesi, 33-34.

25 Abdülkadir Dündar, “Karapınar Sultan Selim Camii’nin Mimarı Hakkında Yeni Bir Kayıt ve Bazı Mülahazalar," Türkiye Büyük Millet Meclisi’nin Açılışının 80. Yıldönümü Karapınar Sempozyumu, 26-27 Ekim 2000, ed. Yusuf Küçükdağ (Konya: Karapınar Belediyesi Yayınları, 2001), 165-174.

26 Gülru Necipoğlu, Sinan Çăğ: Osmanlı İmparatorluğu’nda Mimari Kültür (İstanbul: Bilgi Üniversitesi Yayınlar1, 2013), 81. 
ile cezalarını bulmuşlar idi." ${ }^{27}$ Selim'in askerlerinin Mevlânâ Âsitanesi'nin duvarları dışındaki şehzadeler savaşının yaşandığı "Cem Bağı" adlı bahçede çadırlarını kurmuş olmaları, şehzadenin muharebeden önce şehirdeki türbeleri ziyaret ederek ruhlarından yardım istemesi ve Allah'ın himmetiyle ortaya çıkan ilginç bir mucize ile Celâleddîn Rumî'nin türbesinden yükselen bir toz bulutunun Bayezid'in askerlerini içine alması kaynaklarda anlatılmaktadır ${ }^{28}$.

Necipoğlu, imparatorluk açısından çok önemli bu olay sonrasında yapımına başlanılan Süleymaniye Camii ve Karapınar'da Selim adına inşa edilen yapıların birer zafer anıtı, kutlu bir olayın nişaneleri olduğuna işaret eder, nitekim dergâhın yanı başındaki caminin arsası Şehzadenin muzaffer ordusunun kamp yeridir. Aynı zamanda savaşta Şehzade Selim'i destekleyen Mevlevî dergâhı ile bağlantı kurmaktadır. Cami görevlilerinin dergâhtan, Mevlânâ soyuna mensup kişiler arasından seçilmesi geleneği de bu yorumu güçlendirmektedir. Osmanlı hanedan mensuplarının tarikat yapılarına destek vermesinin belirgin örneği olarak Mevlevî dergâhının genişlemesi Sultan II. Selim ve III. Murad zamanlarında bina ettirilen zaviye ve imaret ile devam etmiştir. ${ }^{29}$

\section{Konya Sultan Selim (Süleymaniye) Camii Biçim Özellikleri}

Yapım tarihi ve mimarı üzerinde duracağımız cami, merkezî kubbeli plan şemasına sahip, kareye yakın dikdörtgen harimi önünde yedi hücreli son cemaat yeri revakı olan iki minareli bir yapıdır. Merkezî kubbe, kıble yönünde bir yarım kubbe, doğu ve batı yönlerinde üçer küçük kubbenin örttüğü harimde orta kubbeyi taşıyan iki bağımsız fil ayağı, ayaklar ile kuzey duvarına bitişik ayaklar arasında ikişer sivri kemerin oturduğu birer sütun bulunmaktadır. Kesme taştan yapılmış yapının mukarnas süslemeli cümle kapısından başka iki yanda birer kapısı daha vardır.

Cami hariminin boyutlarına bakıldığında, ortada merkezi kubbenin örttüğü kare sahın 13,53 m (18,00 zira) kenar ölçüsüne sahipken, kıble yönünde yarım kubbe ile örtülmüş mihrap önü bölümü $6,05 \mathrm{~m}$ (8,00 zira), doğu-batı yönlerinde üçer kubbe ile örtülmüş yan sahınlar 6,60 m (9,00 zira) derinliğindedir. ${ }^{30}$ Doğu-batı yönündeki sivri kemerlerin plandaki 1,50 m (2,00 zira) izdüşümleri ile toplamda iç mekân doğu-batı yönünde 29,95 m (40,00 zira) dir. Cümle kapısı yönünde kubbeyi taşıyan ayaklar

27 Âlî Mustafa Efendi, Künhü' 'l-Ahbâr, İstanbul, Nuruosmaniye Kütüphanesi, Nr. 3409.

28 Necipoğlu, Sinan Çăğ: Osmanlı İmparatorluğu’nda Mimari Kültür, 81.

29 Haşim Karpuz, "Mevlânâ Külliyesi” TDV İslam Ansiklopedisi, c. 29 (Ankara: Türkiye Diyanet Vakfı Yayınları, 2004), 448-452.

30 Mimari özelliklerinin anlatıldığı başlıklar altında ve incelenen kemerlerin boyutlarında metrik değerlerin yanında zaman zaman bu değerlerin inşa edildiği dönem kullanılmakta olan "zirâ-1 mi'mar̂̂” cinsinden karşı1ıklarının da verildiği görülecektir. Zirâ-1 mi’marî (veya mimar arşını) için çalışmada kabul edilen değer yüzyıllar içinde küçük farklılıklar göstermekle birlikte 1841 yılında düzenlenerek standarda bağlanan değer 0,757 m’dir. Ayrıca bkz. Mehmet Erkal, “Arşın,” TDV İslam Ansiklopedisi, c. 3 (İstanbul: Türkiye Diyanet Vakfi Yayınları, 1991), 211. 
3,00 m (4,00 zira) kuzey duvarından içeri kadar taşarken kıble yönünde serbest ayakları birbirine bağlayan kemerin plandaki izdüşümü 2,23 m (3.00 zira) ve bu yöndeki toplam ölçü 25,30 m (35,00 zira) dır. Kuzey duvarının ve mihrap duvarının kalınlığı 1,88 m (2,50 zira) olup toplamda bu yönde beden duvarlarına bakıldığında dış ölçü taşmalar olmadan 30,20 m (40,00 zira), diğer yönde ise 33,75 m (45,00 zira) dir. Cümle kapısının her iki yanındaki duvar payandaları iç mekâna 1,12 m (1,50 zira) taşmaktadır. Kuzey beden duvarı üst kata ve minarelere çıkan merdivenlerin olduğu bölümlerde 3,00 m (4,00 zira) kalınlıktadır. Doğu ve batı cephelerine dışarıya taşan payandalar $1,50 \mathrm{~m}$ (2,00 zira), mihrap tarafinda ise $1,88 \mathrm{~m}(2,50)$ zira taşma yapmıştır. Son cemaat yeri revakları ana kütleden iki yanda $1,88 \mathrm{~m}$ (2,50 zira) taşma yaparak $37,50 \mathrm{~m}$ (50,00 zira) boyuna ulaşırken kubbe ile örtülü iki yan kanatta 3 hücre, cümle kapısı aksındaki tonoz örtülü yüksek tavanlı hücreden daha küçüktür. Revak derinliği sütunları bağlayan sivri kemerlerin $0,75 \mathrm{~m}$ (1,00 zira) derinliği dahil 5,60 m (7,50 zira) dır. Cümle kapısı ve her iki yanındaki birer pencerenin planda genişliği içeriden 2,25 m (3,00 zira), dışarıdan dikdörtgen açıklıklı mermer söve iç ölçüsü 1,52 m (2,00 zira) ölçülmektedir. Yapının boyutları döneminin ölçü birimi baz alınarak incelendiğinde anlamlı sonuçlar elde edilmekle birlikte burada amaçlanan zemin izdüşümü ve kesit düzlemlerinde yapıyı benzer büyüklükte Sinan'ın bilinen diğer cami yapıları ile beden duvarları veya açıklıkların boyutları gibi referanslar üzerinden karşılaştırmak, ayrıca kemerlerin kuruluş ilkelerini ortaya çıkararak Sinan mimarlı̆̆ında ve öncesinde inşa edilmiş yapılardan bildiğimiz diğer örnekler ile kıyas yapmaktır.

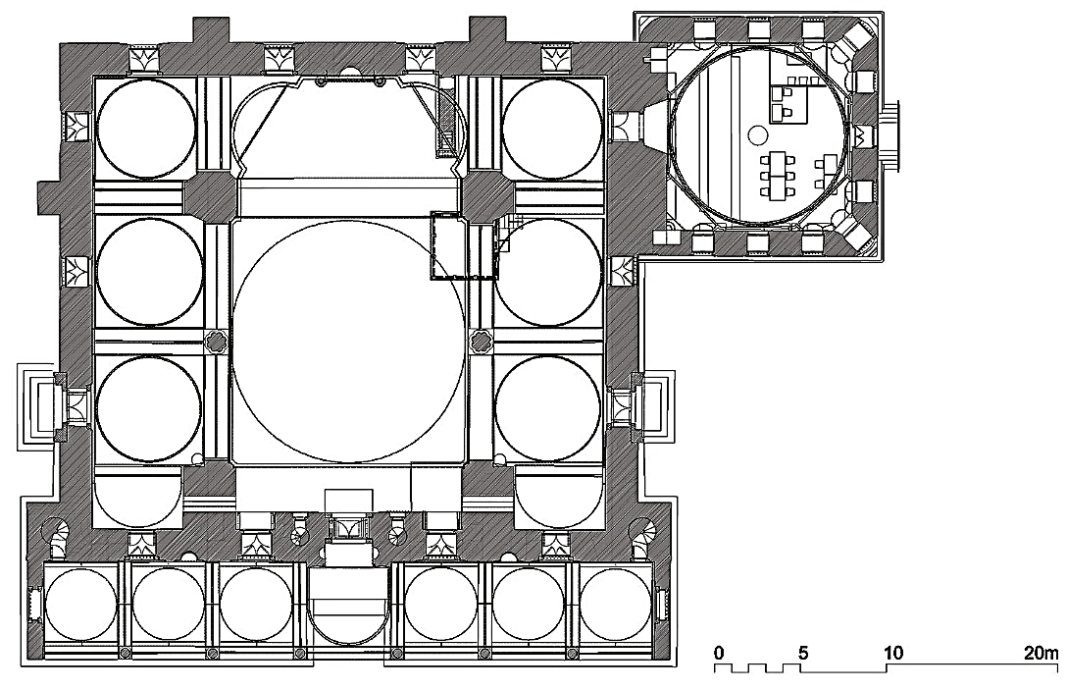

G. 3. Konya Sultan Selim Camii Zemin Plani ${ }^{31}$

31 Konya Vakıflar Bölge Müdürlüğü Arşivi, 30.06.2014 tarihli ve 2094 sayılı Konya Kültür Varlıklarını Koruma Kurulu onaylı Konya Sultan Selim Camii Restorasyon Projesi paftaları kurumdan resmi izin ile alınarak yazar tarafından sayısal ortamda düzenlenmiştir. 
Yapıda kemerlerin kuruluş ilkeleri ve boyutları incelenerek benzer durumlarda tasarımcının tercih ettiği tiplerin diğer yapılar ile ele alınması, müellif mimar konusunda tercih edilen diğer bir sorgulama olacaktır. Cami merkezî kubbesini taşıyan iç mekânın kıble yönündeki serbest iki ayağı birbirine bağlayan kemer, ayakları kuzey yönündeki ayaklara bağlayan kemerler, orta sahnın doğu ve batısında kıble ekseninde kuzey duvarından kıble duvarına devam eden üç sivri kemer, bu ayakları ve sütunları gerilerindeki duvarlara bağlayan kemerler, kuzey duvarında mahfil altındaki kemer, son cemaat yerinde bulunan sivri kemerler ve açıklıklar üzerindeki boşaltma kemerlerinin boyutları ve kemeri oluşturan yayların merkezlerinin yerleri incelenmiştir. İstanbul'da Mimar Sinan'a ait olduğu bilinen 19 camide yaptığımız önceki $\operatorname{araştırmanın~}^{32}$ sonucunda oluşturduğumuz envanter sayesinde bir kıyaslama yapmak mümkün olmaktadır.

\section{Kemerlerin Biçimleniş Özellikleri ve Kıyaslama}

Kubbeyi taşıyan ayakları bağlayan mihrap yönündeki kemerin üzengi hattı yerden yaklaşık 9,90 m (13,00 zira) yükseklikte olup 12,85 m (17,00 zira) açıklığa ve kilit taşı altından üzengi seviyesine 6,50 m (8,50 zira) yüksekliğe sahip daireye yakın iki merkezli sivri kemerdir. Planda derinliği 2,25 m (3,00 zira) cephede genişliği 0,75 m (1,00 zira) olan kemerin yay merkezleri arasında $0,55 \mathrm{~m}$ gibi bir mesafe bulunmaktadır. Diğer yönde kubbeyi taşıyan ve dışarıdan yapıya hâkim merkezde yükselen kübik bölümün doğu ve batı taraflarında görünen kemerlerin açıklığı 13,70 m (18,00 zira) olsa da burada simetri bozulmuş ve türbe yönündeki kemerin planda derinliği 1,50 m (2,00 zira) iken batı yönündeki kemer dıştan tuğla bir kemer daha inşa edilerek desteklenmiş, kalınlığı 2,25 m (3,00 zira) olarak duvar dış cidarı ile hemyüz olmuştur (G. 4). Kuzey duvarının üstünde zeminden 9,75 m (13,00 zira) yükseklikte zemin kotu bulunan 3,80 m (5,00 zira) derinliğe ve 11,45 m (15,00 zira) genişliğe sahip mahfilin üzerindeki kemer mihrap yönündeki ile eş boyutludur. Bu kemerin altında cümle kapısinın üzerinde bulunan 2,65 m (3,50 zira) derinlikli kemer ise merkezi zeminden 2,25 m (3,00 zira) yüksekte bulunan 13,40 m (18 zira) açıklıklı yuvarlak kemerdir. Bu tür geniş açıklık ve kuzey duvarı içinde mahfil üst örtüsü gibi yerlerde bu tip kemerlerin kullanımı yaygındır. Daha belirgin olarak açıklığın 5, 7, 9 gibi bölünmesi ile kurulan sivri kemer tipleri diğer yapılarda da serbest taşıyıcı ayaklar ve alt kotlarda kullanılmıştır. Harimde ayakları sütunlara bağlayan sivri kemerler bu açıdan önemlidir.

32 Ali Naci Özyalvaç, “İstanbul'da Mimar Sinan Camilerinde Sivri Kemer Biçimlenişleri” (Doktora Tezi, Yıldız Teknik Üniversitesi, 2017), 509. 

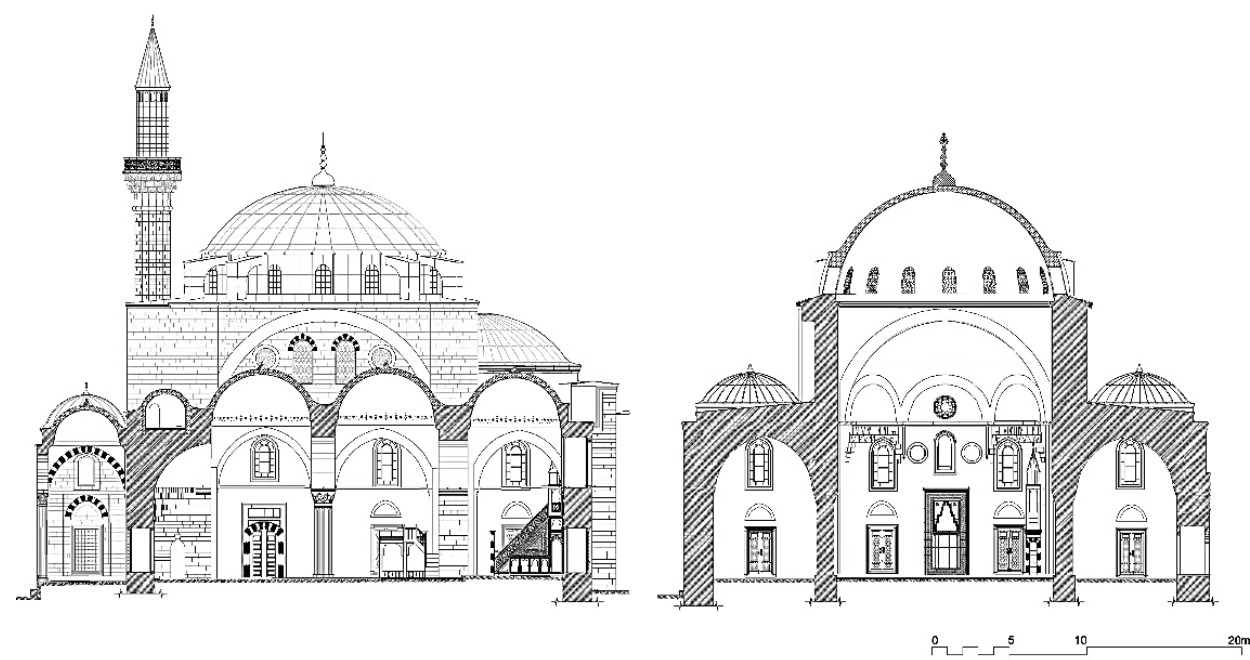

G. 4. Konya Sultan Selim Camii ${ }^{33}$ Solda (a) Kıble ekseninde ve Sağda (b) Boyuna Kesit

İç mekânda kıble yönündeki serbest ayaklar ile kuzeylerindeki sütunları bağlayan 8,00 zira $(6,00 \mathrm{~m})$ açıklığa ve planda 2,00 zira $(1,52 \mathrm{~m})$ derinliğe sahip kemerler açıklığın 5'e bölünmesi ile kurulmuş pencî (beşlik) kemerlerdir. Yay merkezlerinin yerden yüksekliği ortada 7,5 zira (5,60 m) ölçülmektedir. Ayaklar arasındaki sütunları iki yönde ayaklara ve doğu-batı duvarlarına bağlayan sivri kemerlerin tümü benzer açıklığa sahip beşlik kemerlerdir. Mihrap duvarına ayakları bağlayan kemerler de aynı şekilde açıklığı daha küçük 5,30 m (7,00 zira) olan beşlik (1:5) sivri kemerlerdir.

Harimin doğu - batı cephelerinde küçük kubbelerin altında pencere ve kapıların üzerinde aynı kotta benzer beşlik sivri kemerler bulunur. Bu gibi yakın açılılı ölçüsüne sahip kemerlerin takye kotunda (kemer açıklığı üst kotu) aynı üst seviyede olacağı durumlarda, kemer yaylarının merkezleri üzengi seviyesi altında veya üstünde tutularak kemer profilinin korunmasının sağlanması uygulaması burada da görülmektedir. Kemer boşluklarının tepe kotları arasında $12-18 \mathrm{~cm}$ gibi ihmal edilebilir farklılıklar bulunsa da duvar örgüsü ile bu fark tolere edilebilmektedir. Asıl önemli nokta, bu açıklık ölçüsünde pencî (beşlik) kemer uygulamasının benzerlerinin olup olmadığıdır. Kemerlerin sıvanmış bölümlerinin olması, duvar içinde kalması gibi sebepler nedeniyle malzeme ve renkli taş kullanımı bahsine girilmeyecektir. Bunlar dışında harimin doğu ve batı cephelerinde kubbeli bölümlerin altında dışa taşkın duvar payandaları arasında bulunan kemerler tabii olarak simetriktir. Zemin katta bulunan dikdörtgen açıklıklı mermer söveli pencere açıklıklarının üzerinde bulunan $2,00 \mathrm{~m}$ (8/3 zira) açıklıklı boşaltma kemerleri ve ikinci kat pencerelerindeki üstten teğetli kemerlerde pencî (beşlik) tip görülmektedir.

33 Konya Vakıflar Bölge Müdürlüğü Arşivi, Konya Sultan Selim Camii Restorasyon Projesi paftaları kurumdan resmi izin ile alınarak yazar tarafından sayısal ortamda düzenlenmiştir. 


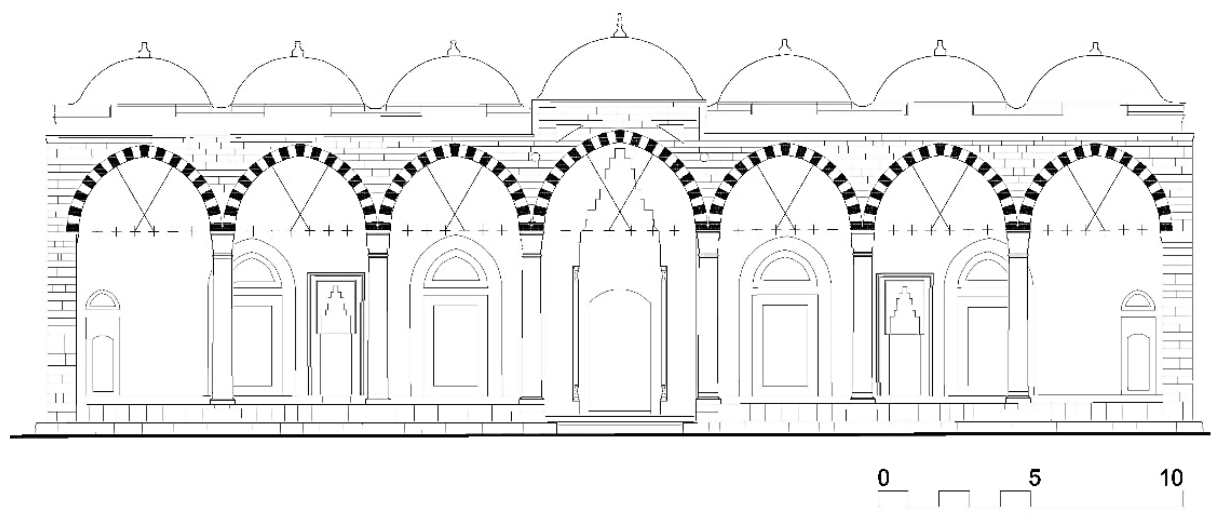

G. 5. Konya Sultan Selim Cami Son Cemaat Yeri, Kuzey Cephesi Görünüş ${ }^{34}$

Son cemaat yeri revak1, ortada daha geniş ve yüksek, iki yanda üçer adet eş boyutlu olmak üzere iki yanda duvarlara ve ortada 6 sütuna oturan yedi sivri kemerle kurulmuştur. Sütun başlıkları planda 0,75 x $0,75 \mathrm{~m}$ (1,00 x 1,00 zira), yan birimlerin açıklığ 4,25 m (5,5 zira) ve ortada cümle kapısı aksını vurgulayan birimde kemer açıklığ yaklaşık $0,75 \mathrm{~m}$ (1,00 zira) daha büyük olup iki yandaki duvar kalınlığ 0,95 m (1,25 zira) ölçülmektedir. Cephede görülen ve sütunları kuzey duvarına bağlayan kemerlerin tümü açıklığın 7'ye bölünmesi ile bulunan noktalardan çizilen yaylardan oluşan iki merkezli yedilik sivri kemerlerdir. (G. 5) Oturduğu zeminden 5,67 m (7,50 zira) yüksekte üzengi seviyesinden başlayan ve alın genişliği $0,38 \mathrm{~m}$ (0,5 zira) olan kemerler 15 renkli ve 14 beyaz taştan oluşmuştur. Son cemaat yerinde kullanılan tek tip ile içeride tekrar eden diğer bir tip yapıda az sayıda kemer tipinin kullanıldığını gösterirken tasarımın olgunluğu ve üslup birliği açısından üzerinde ihtimam gösterilen bir eser olduğu söylenebilir. Nitekim daha önceki çalışmalarımızdan hareketle paşa külliyesi gibi banisi nispeten önemsiz yapılarda daha çok tipin bir arada görüldüğü, selatin camileri gibi büyük yapılarda ise daha az tipin bir arada kullanıldığı bilinmektedir. Bununla birlikte döneminin sanatsal başarı ölçütü olarak matematiksel dakiklik, başka bir deyişle hendesî bileşenlerin bütünde az sayıda oran ilişkisi ile tanımlanmasına gayret edildiği konusu gündeme gelmektedir. Çalışmanın ileriki bölümlerinde yapı bu yönden ayrıca ele alınmaktadır.

Kullanılan kemerlerin açıklık ve kuruluş tiplerine göre İstanbul'da Mimar Sinan döneminde yapılan 19 yapıda kullanılan kemerler ile kıyaslamasını mümkün kılacak katalog çalışması daha önceki tez çalışmalarımızda yer almaktadır. Öncelikle Sultan Selim Camii, plan şeması olarak merkezî kubbeyi dört ayağın taşıdığı grup içinde bulunmaktadır. Bu tipin önemli özelliği ana kubbeyi taşıyan askı kemerlerinin altı ve

34 Konya Vakıflar Bölge Müdürlüğü Arşivi, Konya Sultan Selim Camii Restorasyon Projesi paftaları kurumdan resmi izin ile alınarak yazar tarafından sayısal ortamda düzenlenmiştir. 
sekiz ayaklı plan şemalarından daha büyük boyutlarda olmasıdır. Bu yüzden plan şemasında kubbenin beden duvarları yanında serbest taşıyıcı ayaklara oturduğu bu tipte yapılar önem kazanmaktadır. Diğer bir biçimsel belirleyici olarak beden duvarlarının kuruluşu gösterilebilir ancak bu yapıda boyutları bakımından harim bölümü önemli ölçüde geniş olmakla birlikte beden duvarlarında diğer Sinan dönemi yapılarında görmeye alışık olduğumuz kemerli boşaltma uygulaması görülmez. Üsküdar Atik Valide Camii (1547) yaklaşık 18,00 m x 23,90 m (24,00 x 32,00 zira) harim ölçüleri ve plan şeması ile benzer bir yapı olarak incelenirse duvar payandalarını yukarıda birbirine bağlayan kemerler ile nişler oluşturularak duvar kalınlığının azaltıldığı görülür.

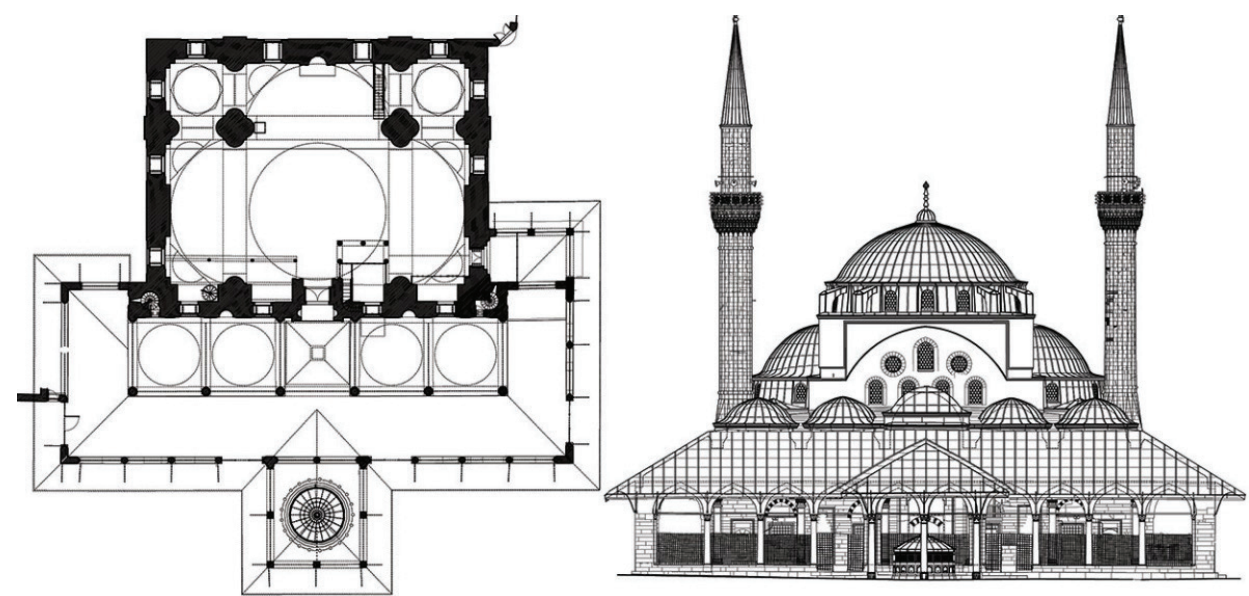

G. 6. Üsküdar Mihrimah Sultan Camii ${ }^{35}$ Solda (a) Zemin Planı ve Sağda (b) Kuzey Cephesi Görünüş

Yine tek kubbeli erken tarihli bir yapı olan Bâli Paşa Camii (1546) örneğinde, kubbenin oturduğu kare planlı harimi çevreleyen beden duvarlarında derin payandalar, iç mekâna doğru taşarak üst kat mahfilin içine girdiği boşaltmalar yapmaktadır (G. 7). Bu yap1, revak kemerleri ve kubbesinin yeniden inşa edilmesi sebebiyle diğer özellikleri bakımından ele alınmaya uygun değildir. Ancak ana kubbeyi taşıyan kemer açıklığ yine 11,10 m (15,00 zira) ölçülür. Bâli Paşa Camii ile benzer ölçü ve plan şemasına sahip Hadım İbrahim Paşa Camii, yine kubbeyi taşıyan duvarların payandalı kemer sistemi ile teşkilatlandırılmasına örnektir (G. 8). Bu sayede pencere açılan yüzeyde duvarın kalınlığ 1,10 m'ye (1,50 zira) kadar inmektedir. 23,90 x 34,30 m (yaklaş1k 32,00 x 46,00 zira) harim boyutları ile dört destekli plan şemasına sahip Mimar Sinan Camileri’nin en aydınlık örneği olan Edirnekapı Mihrimah Sultan Camiii'nde (1566) duvar yüzeylerinde boşaltmalar yapılarak içeriye 1şık alma uygulaması, kubbenin yükseltilerek kemerlerin içinin tümüyle açılması sayesinde en üst seviyeye çıkmıştır. $18,45 \mathrm{~m}$ (24,50 zira) açıklığa kemerlerin taşıdığı 20,10 m (27,00 zira) çapındaki

35 İstanbul Vakıflar 2. Bölge Müdürlüğü Arşivinde bulunan rölöve projesi yazar tarafından sayısal ortamda düzenlenmişir. 
büyük merkezi kubbenin yükünü taşıyan kıble yönü beden duvarı pencere kesitinde kalınlık 1,50 m (2,00 zira) olabilmiş, içe ve dışa taşan payandaların sivri kemerler ile birleştiği gotik dönem yapım tarzını anımsatan strüktürel bir kurgu ile iç mekândaki etkisi hafifletilmiştir (G. 9).

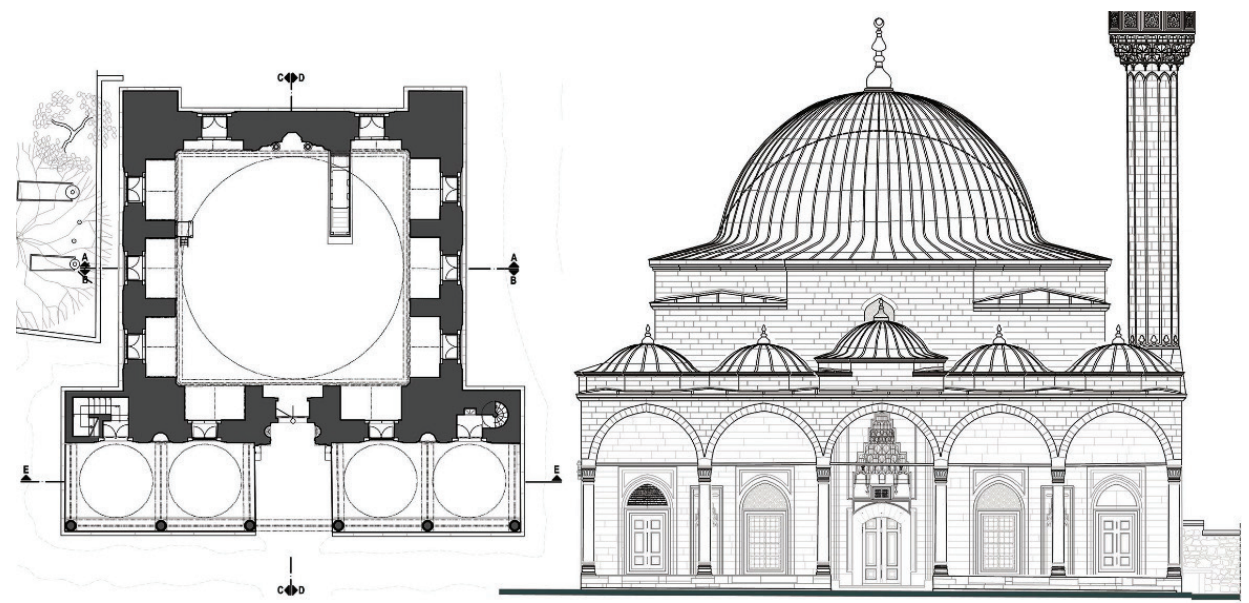

G. 7. Fatih Bâli Paşa Camii ${ }^{36}$ Solda (a) Zemin Planı ve Sağda (b) Kuzey Cephesi Görünüş

Zal Mahmut Paşa Camii (1577) orta kubbeyi taşıyan kemerlerin 12,42 m (16,50 zira) açıklığa ve $6,32 \mathrm{~m}$ (8,50 zira) yüksekliğe sahip olması bakımından da bu yapı ile benzerlik gösterir (G.10). Dört ayaklı plan şemasına sahip her iki yapı da benzer merkezi sahın ölçülerindedir. Bu boyutta büyük kemer kullanımı altı ve sekiz ayaklı yapılarda mümkün olmadığından askı kemerlerinin kıyaslanacağı yapıların dört ayaklı plan şemasına sahip olması akla yatkındır. İç mekânı üç yönde saran üst kat mahfil ve dışarıda kubbe eteği seviyesine kadar yükselen yan bölümleri ve görünüşe hâkim olan taş - tuğla alternatif malzeme kullanımı ile Zal Mahmut Paşa Camii bambaşka bir görünüşe sahip olsa da kullanılan kemer tip ve boyutları, kuzey duvarı tasarımı, camiye üç yönden girilmesi gibi birçok benzer yaklaşım da tespit edilebilmektedir. Bu örnekler birlikte incelendiğinde Sultan Selim Camii duvar teşkilatı bakımından ayrıca ele alınacak olan klasik dönem öncesi yapıları ile daha yakın ilişki kurmaktadır.

36 İstanbul Vakıflar 1. Bölge Müdürlüğü Arşivinde bulunan rölöve projesi yazar tarafindan sayısal ortamda düzenlenmișir. 

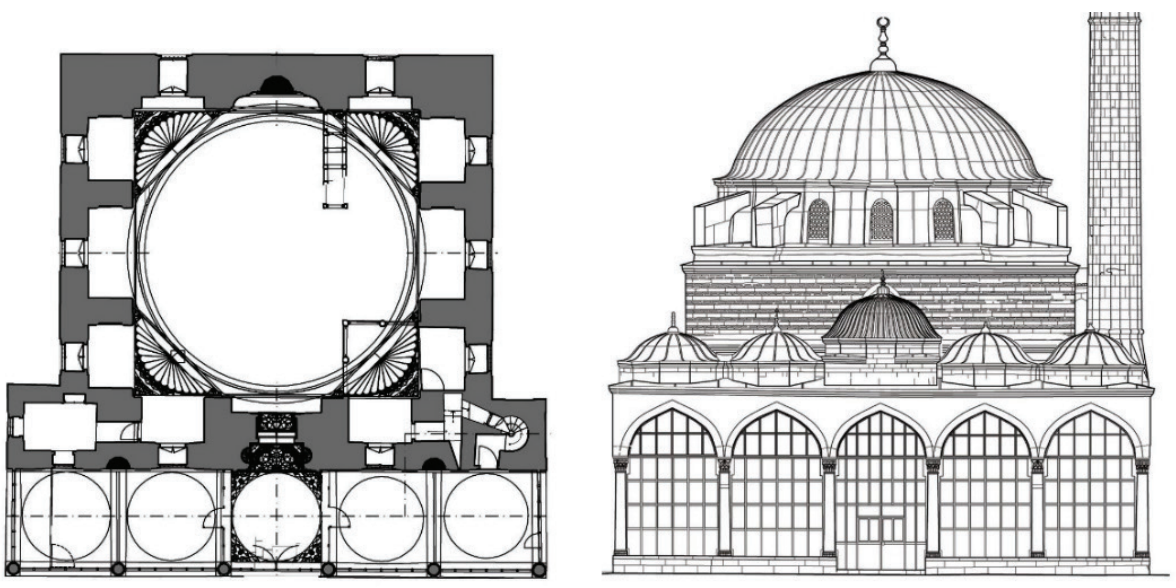

G. 8. Silivrikapı Hadım İbrahim Paşa Camii ${ }^{37}$ Solda (a) Zemin Planı ve ve Sağda (b) Kuzey Cephesi Görünüş
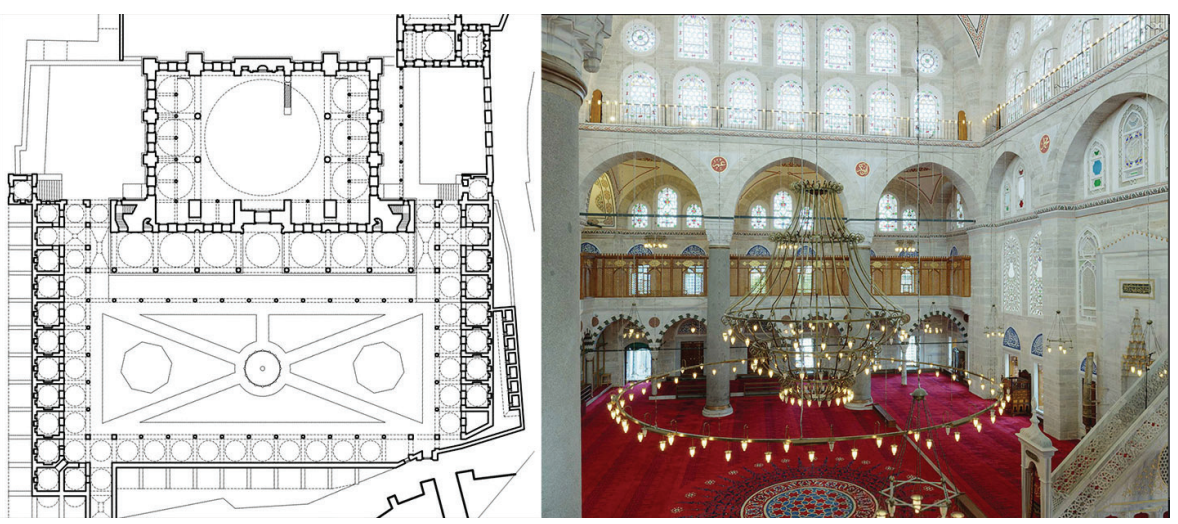

G. 9. Edirnekapı Mihrimah Sultan Camii Solda (a) Zemin Planı (Necipoğlu, Sinan Çağı: Osmanlı Imparatorluğu'nda Mimarî Kültür, 410) ve Sağda (b) İç Mekân Doğu Cephesi Görünüş (Ali Naci Özyalvaç, 2016)

Sultan Selim Camii'nde kubbeyi taşıyan ayaklar arasında yer alan kemer tiplerinin kullanımı ile ilgili olarak kısaca özetlemek gerekirse; 12,85 m (17,00 zira) açıklıklı askı kemerlerinin benzerleri olarak Fatih Bâlî Paşa'nın 11,10 m (15,00 zira) açıklık ve 5,67 m (7,50 zira) yükseklikli dairevi kemeri; Kılıç Ali Paşa Camii’nin 11,35 m (15,00 zira) açıklık ve 6,04 m (8,00 zira) yükseklikli (1:15) oranlı iki merkezli sivri kemeri; Üsküdar Mihrimah Sultan Camii'nin yine 11,10 m (15,00 zira) açıklık ve 5,80 m (7,75 zira) yükseklikli (1:11) oranlı sivri kemeri; Eyüp Zal Mahmut Paşa Camii'nin 12,38 m (16,50 zira) açıklık ve 6,70 m (9,00 zira) yükseklikli (1:11) oranlı sivri kemeri göze çarpmaktadır. Süleymaniye ve Şehzadebaşı Camileri plan tipi benzer olmakla birlikte kemer boyutlarının büyük olması sebebiyle dışarıda tutulmaktadır.

37 İstanbul Vakıflar 1. Bölge Müdürlüğü Arşivinde bulunan rölöve projesi yazar tarafindan sayısal ortamda düzenlenmişir. 


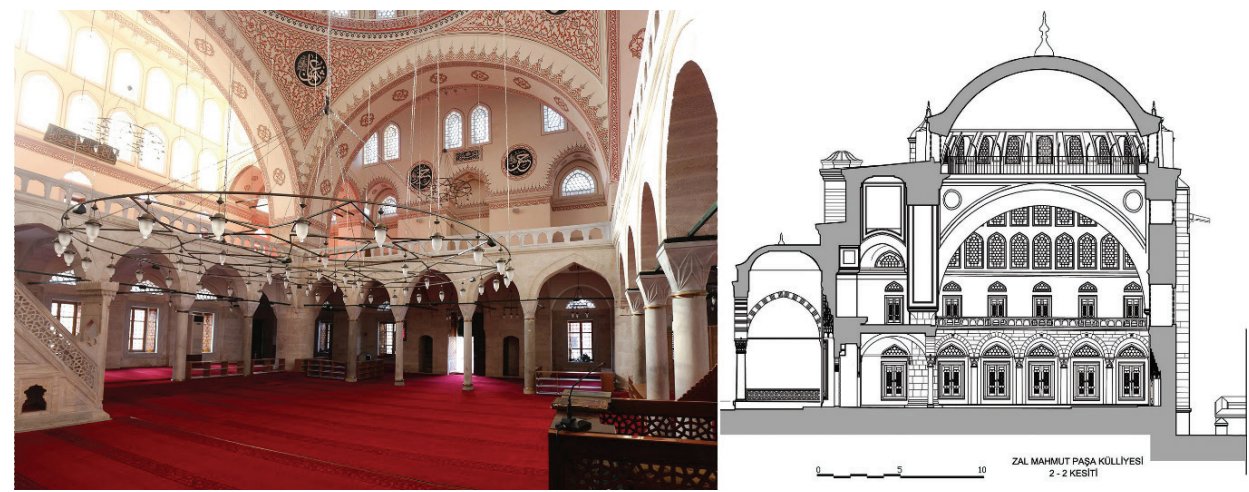

G. 10. Eyüp Zal Mahmut Paşa Camii Solda (Ali Naci Özyalvaç, 2016) (a) İç Mekân Görünüşü ve Sağda (b) Mihrap-Cümle Kapısı Aksından Kesit ${ }^{38}$

İncelediğimiz yapıda harimde sütun başlıklarının başladığı seviyede ayaklar ile beden duvarları ve sütunlar arasında rastladığımız tümü benzer ve ortalama $6,00 \mathrm{~m}$ (8,00 zira) açıklıklı beşlik (pencî) sivri kemerlerin diğer yapılarda kullanım ağırlığı hakkında bir kıyas yapıldığında öncelikle bu kemer tipinin Mimar Sinan devrinde İstanbul'da inşa edilmiş ve incelediğimiz 19 yapı içinde iç mekânda \% 40 ile en çok tercih edilen tip olduğu görülmektedir. Açılıl̆ğn 9, 11 ve 7'ye bölünmesi ile bulunan merkezlerden çizilen iki merkezli sivri kemerler bu tipten sonra aynı ağırlık oranı ile tercih edilmiştir. Avlu, son cemaat yeri ve cephelerde hesaba katıldığında yine beşlik (pencî) kemerin her üç kemerden biri olduğu görülmüştür. Geniş açıklıklarda nadiren kullanılmış olup istisnai örneği Şehzadebaşı Camii'nin askı kemerleridir (G. 11). Üst kotlarda ve büyük açıklıklarda genel eğilim yay merkezlerinin birbirine yakın olduğu yarım daireye yakın tiplerin kullanımıdır. Sekiz destekli plan şemasına sahip Fatih Nişancı Mehmet Paşa ve 6 destekli şemaya sahip Fındıklı Molla Çelebi ve Topkapı Kara Ahmet Paşa Camileri askı kemerlerinin bu tipte olduğu (1:5) daha küçük açıklıklı uygulamalarıdır. Duvardan içe taşan payandaların üzerinde, iç mekânın üst kotlarında, harimin görünüşüne hâkim unsurlar olarak karşımıza çıkan pencî kemerlere yine Şehzadebaşı, Süleymaniye, Üsküdar Atik Valide, Azapkapı Sokullu Mehmet Paşa ve Üsküdar Mihrimah Sultan Camii'lerinde rastlanmıştır.

Zemin kat pencere açıklıkları üzerindeki hafifletme kemerlerinde ekseriyetle kullanılmış olan beşlik pencî sivri kemer tipinin Eminönü Rüstempaşa, Üsküdar Şemsi Ahmet Paşa, Mesih Mehmet Paşa, Nişancı Mehmet Paşa veya Piyale Paşa Camii’lerinde aynı yaklaşımı sergileyen örneklerinin ayrıca açıklık boyutları bakımından tek tek ele alınmasına bu çalışma kapsamında girilmemiştir. Açıkıı ölçüsü bakımından bu tipe ait benzer örnekler incelendiğinde sütun ve payeleri bağlayan iç mekândaki sivri kemerlerin Fındıklı Molla Çelebi Camii’nde 5,67 m (7,50 zira) açıklıklı, Topkapı

38 İstanbul Vakıflar 1. Bölge Müdürlüğü Arşivinde bulunan rölöve projesi yazar tarafından sayısal ortamda düzenlenmişir. 
Kara Ahmet Paşa Camii'nde 5,93 m (8,00 zira) ve Şehzadebaşı Camii'nde 5,70 m (7,50 zira) açıklıklı olarak, yakın ölçülerde yine Süleymaniye Camii’nde 6,80 - 7,00 m (9,00 zira) açıklığa sahip olanları tespit edilmektedir. ${ }^{39}$
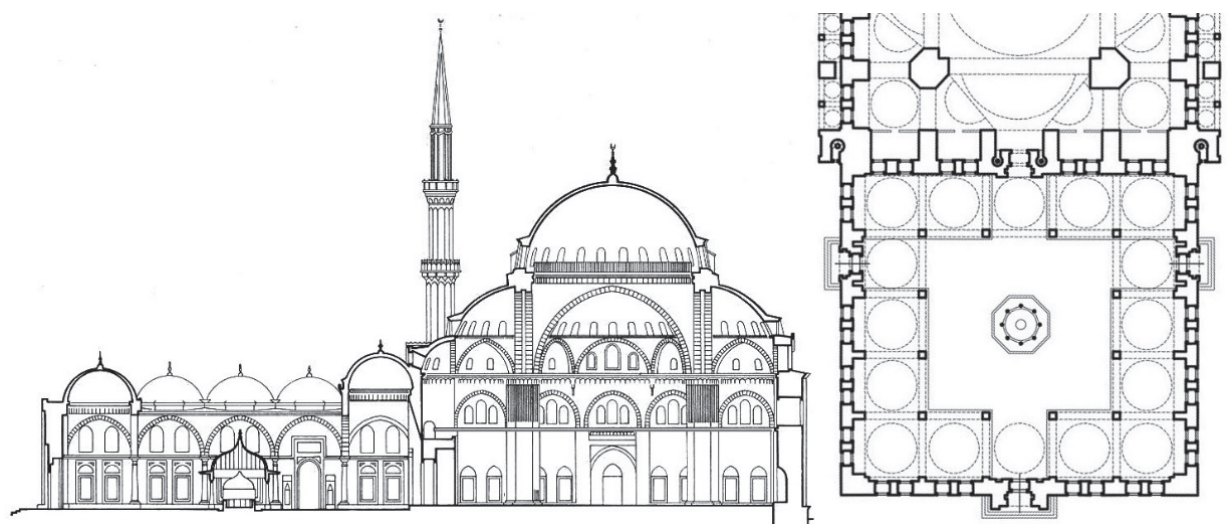

G. 11. Şehzadebaşı Camii Solda (a) Boyuna Kesit (Gurlitt, Die Baukunst Konstantinopels, 1912, Fig. 18a, http://dome.mit.edu/handle/1721.3/65891) ve Sağda (b) Kısmî Plan (Necipoğlu, Sinan Çă̆l: Osmanlı İmparatorluğu'nda Mimarî Kültür, 258)

Günümüzün gelişmiş ölçüm teknolojilerine karşın yapının uzun yaşamı boyunca geçirdiği onarım ve yapısal oturmalar göz önünde bulundurulması gerekirken bu tür yapıların cümle kapısı-mihrap ekseninde aksiyal simetrik olmaları ve revak gibi bölümlerin tekrarlı yapısı, aynı birimlerin özgün boyutlarına ulaşmak bakımından kolaylık sağlamaktadır. Ayrıca yapıda tasarımcının tümel ölçülerde oran kurgulaması ile sivri kemerler gibi bileşenlerin uygulamada kolaylık getirmesi bakımından hendesî kuruluş ilkelerine bağlı olarak tarif ve aplike edilmesi ayrı ele alınması gereken iki farklı durumdur. İlkinde mekân ve kitle etkisi hedeflenirken ikincisinde modüler koordinasyon, imalatta standartlaşma ile üslup birliği ve uygulama kolaylığı sağlanmaktadır. ${ }^{40}$

Son cemaat yeri revaklarında tek sayıda birim kullanılması, ortadaki bir veya üç birimin bazen daha geniş açıklıklı kemerler ile bazen de merkezlerin üzengi seviyesinin üstünde tutularak yükseltilmesi ile giriş aksının belirtilmesi klasik mimaride örnekleri olan uygulamalardır. Haseki Hürrem Camii son cemaat yerinin tuğladan teğetli beş sivri kemerden cümle kapısı aksındaki (orta) kemer yükseltilmiştir. Üsküdar Mihri-

39 Yapılarda burada bahsedilen kemerlerin nerede konumlandıkları ve diğer boyut özellikleri gibi bilgiler için bkz. Ali Naci Özyalvaç, "İstanbul’da Mimar Sinan Camilerinde Sivri Kemer Biçimlenişleri” (Doktora Tezi, Yıldız Teknik Üniversitesi, İstanbul, 2017).

40 Yapının kitle kompozisyonu ve hacim boyutları açısından oran araştırması ayrıca yapılacaktır. Kemer gibi bileşenlerin iki boyutlu hendesî unsurlar olarak düşünüldüğü ve (örneğin tiplerin açıklık / yükseklik nispeti gibi iç bağıntılarının) tasarımcının çalışmaya başlamadan önce hazır olduğu konusunda daha detaylı bilgi ve mesâha ilmi üzerine daha önce yaptığımız çalışmalar için bkz. Ali Naci Özyalvaç, "El-Kâşî’nin "Miftâh El-Hisâb” Adlı Eseri ve 16. Yüzyıl Osmanlı Yapılarında Kemer Biçimlenişleri Üzerine Bir İnceleme,” II. Türkiye Lisansüstü Çalışmalar Kongresi Bildiriler Kitabı-V. Bursa: Bursa Büyükşehir Belediyesi Kitaplığı, 2013, 1221-1237. 
mah Sultan Camii son cemaat yerinin beş birimli ilk sıra revaklarında 5,17 m (7,00 zira) açıklığa sahip yedilik sivri kemerler burada görülen revak kemerleri ile oldukça benzer niteliktedir (G. 6). Yedilik sivri kemer Şehzadebaşı Camii iç mekânında doğu ve batıdaki giriş kapılarının üzerinde duvar payandalarını birbirine bağlarken avlu revaklarında kuzey avlu kapısı önünde de 7,23 m (yaklaşık 10 zira) açıklık geçmek için kullanılmıştır. Süleymaniye Camii avlu revakları (G. 12) son cemaat yeri ile bütünleşik bir örnek olarak hem beşlik hem yedilik sivri kemerin kullanıldığı, ayrıca avlunun kuzey yönünde tümü beşlik sivri kemerlerin ortadaki üçünün yükseltilmesi ile girişin vurgulandığ 1 bir başka örnektir. Burada geçilen açıklık benzer şekilde 5,95 m (8,00 zira) ölçülmektedir.

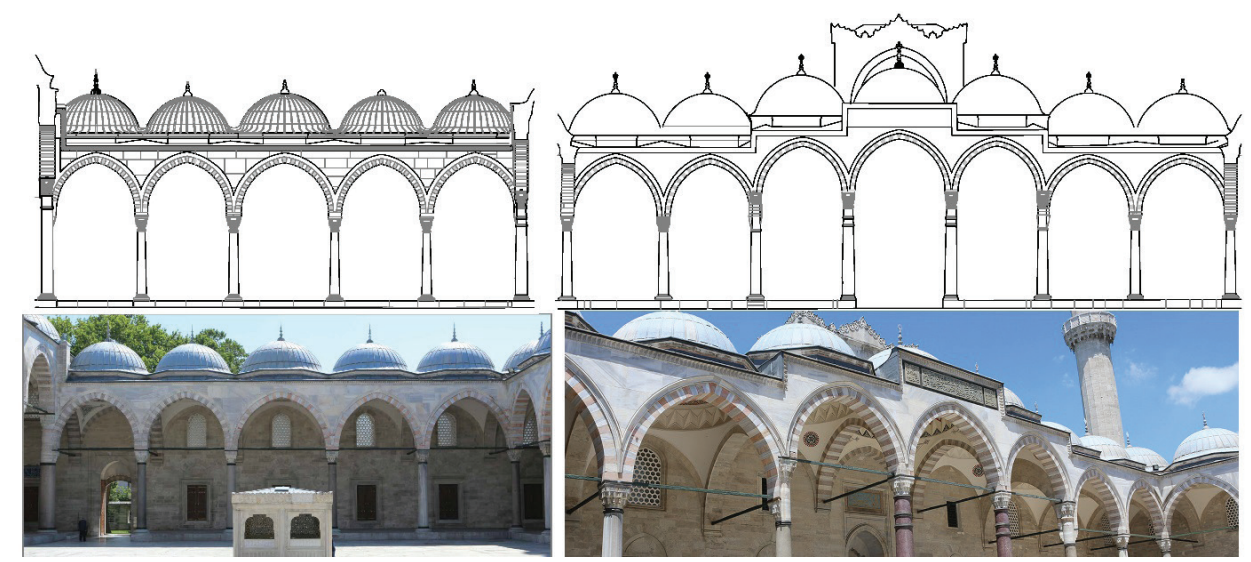

G. 12. Süleymaniye Camii Şadırvan Avlusu Solda (a) Batı Kanadı ve Sağda (b) Kuzey Yönü Revakları1 ${ }^{41}$. Alt kısımda aynı bölümlerin fotoğrafları (Ali Naci Özyalvaç, 2016)

Eyüp Zal Mahmut Paşa Camii'nin beş birimli son cemaat yeri revaklarında kullanılan yine Sultan Selim Camii'nde karşımıza çıkan kemerlere çok benzer ölçüde 4,14 m (5,50 zira) açıklıklı yedilik (1:7) sivri kemere sahipse de tek farkı üzengi hattının daha aşağıda, 3,82 m (yaklaşık 5,00 zira) seviyesinde olmasıdır. Taş - tuğla almaşık örülen kemerlerin burada incelediğimiz kemerler ile taş sayısı ve kemer kalınlığı olarak da benzeştiği görülmektedir. Yedilik sivri kemerin dış mekânda diğer örneklerine Üsküdar Atik Valide Camii son cemaat yeri ilk sıra revaklarının doğu ve batı cephelerinde 4,45 m açıklıklı olarak rastlıyoruz (G. 13). Bu tip (1:7) iki merkezli sivri kemerin Mimar Sinan dönemi İstanbul'unda inşa edilmiş önemli yapılar içinde son cemaat yeri ve avluda tercih edilme oranı, kemer yaylarının merkezleri arasındaki uzaklık / toplam açılık baz alınarak yapılan bir sıralamada ilk beş içinde yer almakla birlikte ağırlıklı olarak (1:5), (1:5,5), (1:4,5) ve (1:9) oranlı sivri kemerlerin seçildiği görülmektedir.

41 İstanbul Vakıflar 1. Bölge Müdürlüğü Arşivinde bulunan rölöve projesi yazar tarafindan sayısal ortamda düzenlenmiştir. 

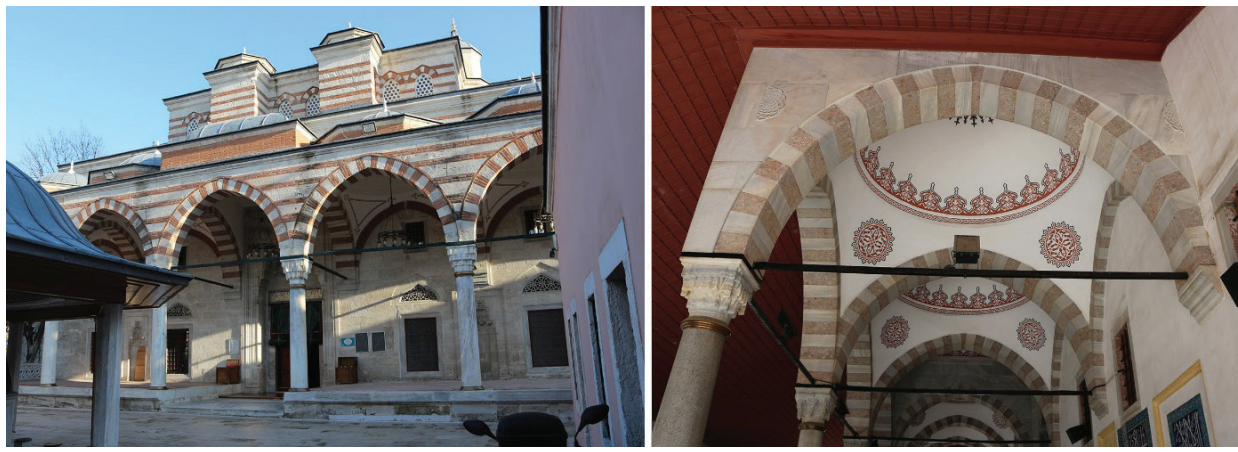

G. 13. Solda (a) Zal Mahmut Paşa Camii Giriş Cephesi ve Sağda (b) Valide-i Atik Camii Son Cemaat Yeri İç Revakları Batı Cephesi (Ali Naci Özyalvaç, 2015)

\section{Sonuç}

İncelemiş olduğumuz Konya Sultan Selim (Süleymaniye) Camii ile ilgili çalışmamızın ilk kısmına dair elde edilen sonuçları özetlemek gerekirse; öncelikle yapının boyut özellikleri inşa edildiği dönemin ölçü birimleri ile yeniden tanımlanmış ve modüler tasarım kurgusu üzerine ileride yapılacak daha detaylı yorum ve karşılaştırmalar için güncel rölöveler yeniden ele alınmıştır. Kubbe çap1, kemer açıklıkları, duvar kalınlıkları gibi büyüklükler bakımından yapının diğer yapılar ile kıyaslandığında inşa edildiği dönem ve müellifi hakkında yapılan Sinan üslubuna göre kitle etkisinin erken dönem yapılarına yakın olduğu şeklindeki genel değerlendirme haklı görünmektedir. Nitekim bu yargıya ulaşmak için cephe görüntüsü yeterli olmaktadır. Ancak yapıda kubbeyi taşıyan kemerler, bir alt kotta ayakları ve duvarları birbirine bağlayan kemerler, son cemaat revakı ve hafifletme kemerlerine bakıldığında yapının şimdiye dek bilinmeyen başlıklar altında incelenmesi mümkün olmaktadır.

Kubbeyi taşıyan ayakları bağlayan mihrap yönündeki kemer ile merkezde yükselen kübik bölümün doğu ve batı taraflarında görünen kemerleri Fatih Bâlî Paşa Camii, Kılıç Ali Paşa Camii, Üsküdar Mihrimah Sultan Camii ve Eyüp Zal Mahmut Paşa Camii askı kemerlerinin benzer örnekleridir. İç mekânda kıble yönündeki serbest ayaklar ile kuzeylerindeki sütunları bağlayan ve ayaklar arasındaki sütunları iki yönde ayaklara ve doğu-batı duvarlarına bağlayan sivri kemerlerin tümü benzer açıklığa sahip beşlik kemerlerdir. Bu yaygın tipin aynı konumdaki benzer boyutlu uygulamaları Fındıklı Molla Çelebi Camii'nde, Topkapı Kara Ahmet Paşa Camii’nde, Şehzadebaşı Camii'nde ve Süleymaniye Camii'nde bulunmaktadır. 6 sütuna oturan yedi sivri kemerle kurulmuş olan son cemaat yeri revakında giriş kapısı aksını vurgulayan ortadaki kemer daha büyük açıklığa sahip ve daha yüksek olup kemerlerinin tümü iki merkezli yedilik (1:7) sivri kemerlerdir. Bu tipin son cemaat yeri revaklarında benzer boyutta kullanımı Eyüp Zal Mahmut Paşa Camii’nde ve Üsküdar Mihrimah Sultan Camii’nde, 
Üsküdar Atik Valide Camii'nde ve Süleymaniye Camii'nde bulunmaktadır. Yine orta hücrenin yükseltilmesi uygulamasının benzer diğer örneklerine yukarıda değinilmiştir.

Burada kıyas yapılırken bahse konu olan eserlere bakıldığında Haseki Hürrem 1538, Bâli Paşa 1546, Üsküdar Mihrimah Sultan 1547, Şehzadebaşı 1548, Hadım İbrahim Paşa 1551, Süleymaniye 1557, Topkapı Kara Ahmet Paşa 1560 ve Rüstem Paşa Camii 1561 tarihli olup tümü Sultan Selim Camii’nin inşa edildiği iddia edilen tarihten önce Mimar Sinan döneminde hayata geçirilmiş önemli eserlerdir. Beşlik pencî (1:5) ve yedilik (1:7) iki merkezli sivri kemer uygulamalarının iç mekânda, son cemaat yerinde, avluda ve cephelerde benzer kullanımları araştırılırken, plan özellikleri bakımından duvar teşkilatı ve destek payandalarının planda iç mekân kuruluşuna katılışı konusu irdelenirken bu mevcut eserlerin varlığı ile ortaya çıkan tecrübenin bu yapıda kullanılmış olduğu da ortaya çıkmaktadır.

Zal Mahmut Paşa, Üsküdar Atik Valide Camileri hemen hemen aynı kemerlerin aynı konumlarda kullanıldığı daha geç dönem yapılar olarak belirtilmiştir. Beşlik (pencî) kemerler ise tüm klasik dönem içinde yoğun kullanım oranına paralel olarak burada da tercih edilmiş, iç mekâna hâkim unsurlar olarak ortaya çıkmıştır. Sinan dönemi İstanbul camilerinde bu konumda 9 farklı tipin daha kullanılmış olduğu bilgisi ortaya konan sonucu ayrıca anlamlı kılmaktadır.

Yapının az sayıda kemer tipinin tekrarı ile oluşturulmuş olması tasarımın olgunluğu ve inşa edilirken ihtimam gösterildiği şeklinde yorumlanabilir; nitekim önceki bulgularımız da selâtin yapılarının büyüklüğüne karşın nispeten daha az sayıda tipe sahip olduğunu göstermektedir. Dönemi içinde bu kaygının yapının üslup birliği ve estetik ifadesinin bütünlüğü ile ilişkili olarak tasavvur edildiği düşünülebilir. Yine yapının klasik dönem Osmanlı mimarlığının yöredeki en mükemmel örneği olarak tanımlanması malzeme kalitesi, işçilik ve bezemeden çok bu olgun ifade sebebiyledir. Burada klasik dönem ifadesinin biçim özellikleri bakımından nasıl ortaya konduğu nispeten analitik gerekçeler ile açıklanmaktadır.

Konya Sultan Selim Camii'nin inşa tarihi konusunda geçmişte kaynaklar daha erken tarihlere işaret etse de güncel kaynakların çoğunda belirtildiği gibi 1559'da Konya'da yaşanan şehzadeler arası mücadelenin neticelenmesi ile II. Selim'in babası Kanunî Sultan Süleyman'ın ölüm haberi üzerine 1566'da tahta çıkması arasında geçen zaman diliminde inşa edilmeye başlamış olduğunu söyleyebiliriz. Bu tarihte Mimar Sinan yaklaşık 30 yıldır mimarbaşı olarak hizmet vermekteydi ve yukarıda bahsedilen önemli eserlerini vücuda getirmiş durumdaydı. Bu bağlamda Mevlevî dergâhının bünyesine katılacak bir selatin camiinin yapımında etkisinin olmaması fikri akla yatkın değildir. Bu noktada Konya Karapınar'da Şehzade Selim tarafından 1560 tarihinde bir cami inşası için Halep'ten ismi verilerek çağırılması istenen Mimar Cemâleddin'in yanında yapının inşasında bulunmak üzere Mimar Mehmet'in görevlendirilmesi, buna 
benzer uygulamaların mümkün olduğunu göstermektedir. Yakın tarihlerde inşa edilmiş her iki yapı için Hassa Mimarlar Ocağı başmimarı Koca Sinan tarafından görevlendirilmiş yardımcı mimar veya mimarların etkili olduğu, bu mimarların muhtemelen daha önceki başmimar Alâeddin Ali Bey zamanından beri ocakta bulunan tecrübeli mimarlar arasından seçildiği, yapının arkaik kitle tesiri hakkında yapılan yorumları anlamlı kılacaktır.

Bir makale hacmine sığmak zorunda kalan bu bölümün devamında yapının bazı yazarlar tarafından Sinan öncesi baş mimarları tarafından yapılmış olduğu iddiasıyla ilgili olarak İstanbul Yavuz Selim Camii gibi bir dizi yapıyla kıyaslanması planlanmaktadır. Karapınar Sultan Selim imareti müellifi Halepli Cemâleddin'in aynı tarihlerde bu yapıda çalışmış olduğu şeklinde öne sürülen tez için de yine yapının biçim özelliklerine müracaat edilmelidir. Sinan öncesi İstanbul ve Edirne'de inşa edilen camilerde görülen tasarım yaklaşımları ve kemer biçimlenişleri devam eden çalışmalardır. Yapıda göze çarpan diğer önemli bir özellik plan ve kesit düzlemlerinde altın kesim gibi belli oranların sürekli tekrar etmesidir. Daha önce Mimar Sinan dönemi yahut seleflerinin yapıları için bu derece açık ve tutarlı bir oran kullanımı bizim bilgimiz dışındadır. İki ayrı çalışma olarak tertip ettiğimiz için burada detaylı bilgi verilmemekle birlikte oran konusu, değerlendirmede göz önüne alınması gereken bir husus olarak ortaya çıkmaktadır.

Hakem Değerlendirmesi: Dış bağımsız.

Çıkar Çatışması: Yazar çıkar çatışması bildirmemiştir.

Finansal Destek: Yazar bu çalışma için finansal destek almadığını beyan etmiştir.

Peer-review: Externally peer-reviewed.

Conflict of Interest: The author has no conflict of interest to declare.

Grant Support: The author declared that this study has received no financial support.

\section{Kaynakça/References}

Âlî Mustafa Efendi. Künhü'l-Ahbâr. Nuruosmaniye Kütüphanesi, Ms. 3409.

Ankara Vakıflar Genel Müdürlüğü Arşivi. 475/7; 734/168.

Arabacı, Caner. Osmanlı Dönemi Konya Medreseleri (1900-1924). Konya: KTO Yayınları, 1998.

Aslanapa, Oktay. Osmanlı Devri Mimarisi. İstanbul: İnkılap Yayınları, 2004.

Atâ Bey. Tarih-i Atâ. 1.cilt. İstanbul: Basiret Matbaası, 1874, 126.

Dündar, Abdülkadir. “Karapınar Sultan Selim Camii’nin Mimarı Hakkında Yeni Bir Kayıt.” Türkiye Büyük Millet Meclisi’nin Açılışının 80. Yıldönümü Karapınar Sempozyumu, 26-27 Ekim 2000. Ed. Yusuf Küçükdağ. Konya: Karapınar Belediyesi Yayınları, 2001, 165-174.

Evliya Çelebi Seyahatnâmesi. Haz. Seyit Ali Kahraman ve Yücel Dağlı. İstanbul: Yapı Kredi Yayınlar1, 2013.

Erkal, Mehmet. “Arşın.” TDV İslam Ansiklopedisi. 3. cilt. (İstanbul: Türkiye Diyanet Vakfı Yayınlar1, 1991), 211. 
Eyice, Semavi. "Cami.” TDV İslam Ansiklopedisi. 7. cilt. İstanbul: Türkiye Diyanet Vakfı Yayınları, 1993, 56-90.

Gurlitt, Cornelius. Die Baukunst Konstantinopels. Berlin: E. Wasmuth, 1912. Erişim 12 Haziran 2020. http://dome.mit.edu/handle/1721.3/65891

Hammer-Purgstall, Joseph Von. Devlet-i Osmâniyye Târihi. 3. cilt. Trc. Mehmed Atâ. İstanbul: Mesai Matbaas1, 1329 [1913].

Hammer-Purgstall, Joseph Von. Devlet-i Osmâniyye Târihi. 6. cilt. Trc. Mehmed Atâ. İstanbul: Nefaset Matbaası, 1332 [1916].

İstanbul Vakıflar 1. Bölge Müdürlüğü Arşivi, 03.12.2008 tarih ve 2235 sayıl1, İstanbul II Numaralı Kültür ve Tabiat Varlıklarını Koruma Bölge Kurulu onaylı Eyüp Zal Mahmut Paşa Camii Rölöve Projesi.

İstanbul Vakıflar 1. Bölge Müdürlüğü Arşivi, 13.12.2007 tarih ve 34 sayıl1, İstanbul Yenileme Alanları Kültür ve Tabiat Varlıklarını Koruma Bölge Kurulu onaylı Hadım İbrahim Paşa Camii Rölöve Projesi.

İstanbul Vakıflar 1. Bölge Müdürlüğü Arşivi, 14.02.2007 tarihli ve 1047 say1lı, İstanbul IV Numaralı Kültür ve Tabiat Varlıklarını Koruma Bölge Kurulu onaylı Süleymaniye Camii Rölöve Projesi.

İstanbul Vakıflar 1. Bölge Müdürlüğü Arşivi, 27.12.2006 tarih ve 9/3 sayıl1, İstanbul I Numaralı Kültür ve Tabiat Varlıklarını Koruma Bölge Kurulu onaylı Fatih Bali Paşa Camii Rölöve Projesi.

İstanbul Vakıflar 2. Bölge Müdürlüğü Arşivi, 07.10.2008 tarih ve 1136 sayılı, İstanbul VI Numaralı Kültür ve Tabiat Varlıklarını Koruma Bölge Kurulu onaylı Üsküdar Mihrimah Sultan Camii Rölöve ve Restorasyon Projesi.

Karaçelebizâde Abdülaziz Efendi. Kitâb-ı Süleymannâme. Kahire: Matbaa-1 Bulak, 1832.

Karpuz, Haşim. "Mevlânâ Külliyesi”. TDV İslam Ansiklopedisi. 29. cilt, İstanbul: Türkiye Diyanet Vakfi Yayınları, 2004, 448-452.

Konya Vakıflar Bölge Müdürlügü Arşivi, 30.06.2014 tarihli ve 2094 sayılı, Konya Kültür Varlıklarını Koruma Kurulu onaylı Konya Sultan Selim Camii Restorasyon Projesi.

Konyalı, İbrahim Hakkı. Âbideleri ve Kitâbeleri ile Konya Tarihi. Konya: Yeni Kitap Basımevi, 1964.

Küçükdağ, Yusuf. "Sultan Selim Camii ve Külliyesi.” TDV İslam Ansiklopedisi. 37. cilt, İstanbul: Türkiye Diyanet Vakfi Yayınları, 2009, 516-517.

Küçükdağ, Yusuf. Karapınar Sultan Selim Külliyesi. Konya: Karapınar Belediyesi Yayınları, 1997.

Kuran, Aptullah. Mimar Sinan. İstanbul: Hürriyet Vakfı Yayınları, 1986.

Necipoğlu, Gülru. Sinan Çăğ Osmanlı İmparatorluğu’nda Mimari Kültür. İstanbul: İstanbul Bilgi Üniversitesi Yayınları, 2013.

Önder, Mehmet. Mevlânâ Şehri Konya. Ankara: Konya Turizm Derneği Yayını, 1971.

Özyalvaç, Ali Naci. "El-Kâş̂̀’nin "Miftâh El-Hisâb” Adlı Eseri ve 16. Yüzyıl Osmanlı Yapılarında Kemer Biçimlenişleri Üzerine Bir İnceleme”, II. Türkiye Lisansüstü Çalışmalar Kongresi Bildiriler Kitabı-V. Bursa: Bursa Büyükşehir Belediyesi Kitaplığ1, 2013, 1221-1237.

Özyalvaç, Ali Naci, “İstanbul'da Mimar Sinan Camilerinde Sivri Kemer Biçimlenişleri.” Doktora Tezi, Yıldız Teknik Üniversitesi, 2017.

Peçevî İbrahim Efendi. Tarih-i Peçevî. İstanbul: Matbaa-1 Amire, 1864.

Solakzâde Mehmed Hemdemî. Solakzade Tarihi. Ankara: Kültür Bakanlığı Yayınları, 1989. 
Sönmez, Zeki. “Acem Ali.” TDV İslam Ansiklopedisi. 1. cilt, İstanbul: Türkiye Diyanet Vakfı Yayınları, 1988, 322.

Sözen, Metin. Türk Mimarisinin Gelişimi ve Mimar Sinan. İstanbul: Türkiye İş Bankası Kültür Yayınlar1, 1975.

Uzluk, Şahabeddin. "İstanbul'daki Eski Fatih Camii'nin Bir Benzeri Konya'da Selimiye Camii." Vak1flar Dergisi IX (1971), 173-181.

https://pbase.com/dosseman/image/131990598 Erişim 12 Haziran 2020.

https://pbase.com/dosseman/image/28778983 Erişim 12 Haziran 2020. 
